\title{
Preliminary results of studies on the distribution of invasive alien vascular plant species occurring in semi-natural and natural habitats in NW Poland
}

\author{
Agnieszka Popiela ${ }^{1}$, Andrzej Łysko ${ }^{2}$, Zofia Sotek ${ }^{1} \&$ Krzysztof Ziarnek ${ }^{3}$
}

\author{
${ }^{1}$ Department of Botany and Nature Conservation, University of Szczecin, Felczaka 3c, 71-412 Szczecin, Poland \\ ${ }^{2}$ Department of Environmental Protection and Management, Western Pomeranian University of Technology, Szczecin, Słowackiego 17, \\ 71-374 Szczecin, Poland \\ ${ }^{3}$ Białostocka 48, 71-039 Szczecin, Poland \\ * corresponding author (e-mail: popiela@univ.szczecin.pl)
}

\begin{abstract}
In Western Pomerania, as in other areas of Europe, alien species play an increasingly important role. In particular, invasive plants tend to spread rapidly and in large numbers which may reduce diversity of native species, leading to the phenomenon of "trivialisation of flora", and transform ecosystems. The list of invasive species (32 taxa) includes alien species occurring throughout Western Pomerania, and penetrating natural or semi-natural habitats. The second group consists of potentially invasive species (23 taxa), i.e. those distributed across the area under study and tending to increase the number of their localities in semi-natural and natural habitats, taxa invasive only locally, as well as species with missing data, which does not currently allow including them into the first group. Invasive weeds, as well as some epecophytes and archaeophytes occurring only on anthropogenic sites and tending to spread, were not taken into account. Among hemiagriophytes, the most common and troublesome ones are: Conyza canadensis, Erigeron annuus, Lolium multiflorum, Lupinus polyphyllus, Solidago canadensis, S. gigantea. Among holoagriophytes, i.e. the taxa which received the highest naturalisation status, very expansive species, successful in land colonisation, like Acer negundo, Bidens frondosa, B. connata, Clematis vitalba, Elodea canadensis, Epilobium ciliatum, Heracleum sosnowskyi, Impatiens glandulifera, I. parviflora, Padus serotina, Quercus rubra and Robinia pseudoacacia, should be given particular attention. Among the invasive and potentially invasive species, most taxa penetrate plant communities of the Artemisietea and Molinio-Arrhenatheretea class, followed by Querco-Fagetea, Vaccinio-Piceetea, Stellarietea mediae, Salicetea purpurae and Koelerio-Corynophoretea. The number of invasive species is twice as high when compared to the situation of these species in Poland; on the contrary, the number of species inhabiting anthropogenic, semi-natural and natural habitats is two times lower, while that of holoagriophytes and hemiagriophytes is $56.3 \%$ and $43.7 \%$, respectively. It seems that in the case of some invasive and potentially invasive species, a decrease in the number of their locations may be observed from the west to the east (e.g. for Acer negundo, Bromus carinatus, Clematis vitalba, Helianthus tuberosus, Lycium barbarum, Reynoutria japonica, Rosa rugosa, Vicia grandiflora). Distribution patterns for some species (e.g. for Parthenocytisus inserta or Xanthium albinum) are indicative of a likely major role of the Odra River valley in the spreading of invasive species. It should be kept in mind that the area of the North-West Poland is poorly examined in terms of its flora, so the results provided in this paper are tentative. Nevertheless, the maps illustrate colonisation trends and directions and, moreover, have been so far the only attempt to synthesise this problem in NW Poland.
\end{abstract}

Key words: potentially invasive species, hemiagriophytes, holoagriophytes, apophytes, neophytes, distribution maps

\section{Introduction}

Western Pomerania is a phytogeographically important region of Europe where the limits of the home ranges of many taxa converge; it is also an area diversified in its habitats and relatively well preserved in terms of natural environment. Floristic data have been systematically collected in this region for more than 150 years, first by German botanists and naturalists and then, after 1945, by Polish scholars (see Ziarnek et al. 2003; Ziarnek 2012). At present, the vascular flora includes approximately 1250 taxa, of which about $20 \%$ 
represent alien species. Unfortunately, as in other areas of Poland and Europe (e.g. Berg \& Barth 2008; Dajdok \& Pawlaczyk 2009; Tokarska-Guzik et al. 2012), some of them are invasive species, i.e. they occur in large numbers, reduce diversity of indigenous species, inducing "trivialisation of flora", and transform ecosystems, or may behave similarly in the nearest future.

Since 2006, we have been conducting studies on building a web-based database system and a distribution atlas of vascular plants and fungi from North-West Poland (Popiela et al. 2013a, 2013b). We have been inspired by well-known developments of that type covering both whole continents (e.g. Jalas \& Suominen 1972-1994; Meusel et al. 1978; Hultén \& Fries 1986; Meusel \& Jäger 1992; Jalas et al. 1996, 1999; Kurtto et al. 2004, 2007, 2010) and distribution atlases prepared for particular countries or regions (e.g. Fukarek \& Henker 2006; Zając \& Zając 2001; Bettinger et al. 2013) as well as web-based information systems operating both on a global (e.g. Global Biodiversity Information Facility, GBIF) and regional basis (e.g. Tela Botanica, Le réseau de la botanique francophone, http://www.telabotanica.org/; Distribution databases and herbariums of Mecklenburg-Pomerania, http://www.flora-mv.de; Belgian Biodiversity Platform, http://data.biodiversity. be; L'atlas de la flore de Wallonie, http://biodiversite. wallonie.be; Das Projekt Datenbank Gefäßpflanzen, http://www.biologie.uni-Regensburg.de/Botanik/).

The aim of this paper is to use the resources of the Western Pomeranian Atlas of Distribution of Vascular Plants and Fungi (in Polish: Zachodniopomorski Atlas Rozmieszczenia Roślin i Grzybów - ZARRiG) for compiling tentative lists of invasive and potentially invasive species in Western Pomerania as well as to present the state of our current knowledge about their resources and distribution.

\section{Material and methods}

The lists of invasive and potentially invasive species were made based on the literature analysis (mainly Berg \& Barth 2008; Dajdok \& Pawlaczyk 2009; TokarskaGuzik et al. 2012), own observations of the authors of this paper, and information of the authors of particular floristic data found in the ZARRiG Atlas resources. A qualification criterion was the prevalence of a species in many locations or the mass occurrence of a species and its tendency to penetrate, besides antropogenic, also semi-natural and natural habitats. Invasive weeds, as well as some epecophytes and archaeophytes occurring only on anthropogenic sites and tending to spread, were not taken into account (i.e. Alopecurus myosuroides, Amaranthus retroflexus, Avena fatua, Digitaria ischaemum, Echinochloa crus-galli, Euphorbia helioscopia, E. peplus, Fallopia convolvulus, Fumaria officinalis,

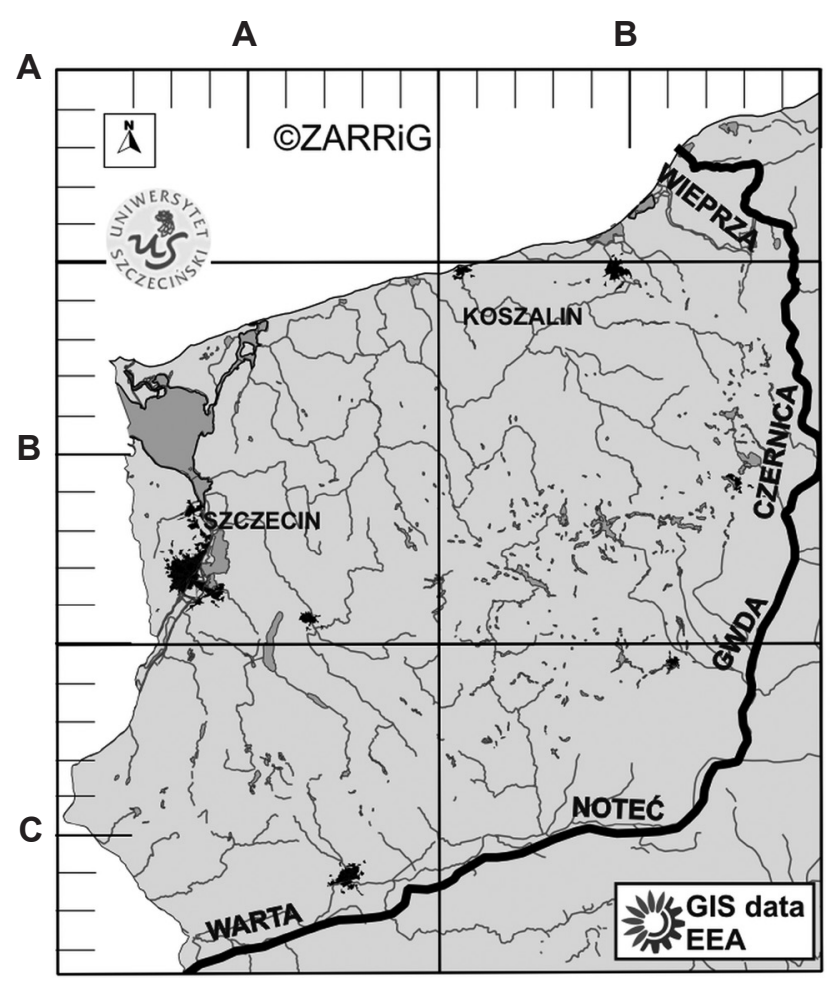

Fig. 1. The geographic coverage of the Western Pomeranian Atlas of Distribution of Vascular Plants and Fungi (ZARRiG) project

Hordeum murinum, Oxalis corniculata, O. fontana, Setaria pumila, $S$. viridis, Veronica persica). The list of invasive species (Table 1) includes species occurring throughout Western Pomerania. The second group consists of potentially invasive species (Table 2), i.e. those distributed across the area under study and tending to increase the number of their localities, taxa invasive only locally as well as species with missing data, which does not currently allow including them in the first group.

Nomenclature was adopted after Mirek et al. 2002. The source of information is the floristic data, published or unpublished, collected so far in the ZARRiG database from botanical, floristic and phytosociological literature (since the beginning of the 19th century), our own materials, herbarium materials, as well as field data specifically gathered for this project. The geographic limits of this project are spatially defined as follows: Poland's border to the west, the Warta and Noteć River Valley to the south, the Gwda, Czernica and Wieprza rivers to the east, and the Baltic Sea coast to the north (Fig. 1).

All floristic data used in this study are available in the ZARRiG database. A single datum comprises the following information: taxon name; cartogram number in the ATPOL system (Zając 1978); geographic coordinates; region, name of location; name (or names) of the author (authors); date of publication, recording 
Table 1. A tentative list of invasive vascular plant species in Western Pomerania (NW Poland)

\begin{tabular}{|c|c|c|c|c|c|}
\hline Species & Area of origin & $\begin{array}{l}\text { Habitats and vegetation (syntaxonomic } \\
\text { class) colonized in Western Pomerania }\end{array}$ & $\begin{array}{l}\text { Type of } \\
\text { habitat in } \\
\text { Western } \\
\text { Pomerania }\end{array}$ & $\begin{array}{l}\text { Geographic- } \\
\text { historical } \\
\text { group in } \\
\text { Western } \\
\text { Pomerania }\end{array}$ & $\begin{array}{l}\text { Type of } \\
\text { habitat } \\
\text { in } \\
\text { Poland }\end{array}$ \\
\hline Acer negundo L. & N Am & $\begin{array}{l}\text { near houses, waysides, forest fringes, } \\
\text { river banks and lake shores, parks and tree } \\
\text { plantings, postindustrial areas, dump sites } \\
(\text { Ar, St, Q-F) }\end{array}$ & ASN & ho & ASN \\
\hline $\begin{array}{l}\text { Anthoxanthum aristatum } \\
\text { Boiss. }\end{array}$ & S Eur & $\begin{array}{l}\text { sandy fields, dump sites, dry grasslands (St, } \\
\text { K-C) }\end{array}$ & AS & he & A \\
\hline $\begin{array}{l}\text { Bidens frondosa } \mathrm{L} .(B . \\
\text { melanocarpus Wiegand) }\end{array}$ & N Am & $\begin{array}{l}\text { lake shores, river and watercourse banks } \\
\text { (B) }\end{array}$ & $\mathrm{N}$ & ho & ASN \\
\hline Bidens connata H. L. Mühl. & N Am & $\begin{array}{l}\text { lake shores, river and watercourse banks } \\
\text { (B) }\end{array}$ & $\mathrm{N}$ & ho & $\mathrm{N}$ \\
\hline Clematis vitalba $\mathrm{L}$. & $\begin{array}{l}\text { C Eur, NW } \\
\text { Afr, Asia } \\
\text { (Caucasus) }\end{array}$ & $\begin{array}{l}\text { shrubs, tree-lines, forests and tree plantings, } \\
\text { oak and Robinia forests, waysides, parks, } \\
\text { cemeteries (R-P, Q) }\end{array}$ & ASN & ho & ASN \\
\hline $\begin{array}{l}\text { Conyza canadensis }(\mathrm{L} .) \\
\text { Cronquist }\end{array}$ & $\mathrm{N}$ Am & $\begin{array}{l}\text { waysides, fallow lands, fields, near houses, } \\
\text { dump sites, pine tree plantings, xerothermic } \\
\text { grasslands, meadow fringes,-pasture lands, } \\
\text { tree clearings, heathlands, levees, forest } \\
\text { edges (Ar, E, K-C, M-A, N-C) }\end{array}$ & AS & he & A \\
\hline Digtalis purpurea $\mathrm{L}$. & W Eur & $\begin{array}{l}\text { waysides and complexes of pine forests, } \\
\text { acid oak and beech forests (Q-F, Q, V-P) }\end{array}$ & ASN & ho & ASN \\
\hline $\begin{array}{l}\text { Echinocystis lobata (F. } \\
\text { Michx.) Torr. \& A. Gray }\end{array}$ & N Am & $\begin{array}{l}\text { shrubs and tall herb along rivers, } \\
\text { wastelands (Ar, M-A) }\end{array}$ & $\mathrm{SN}$ & he & ASN \\
\hline Elodea canadensis Michx. & N Am & $\begin{array}{l}\text { ponds, ditches, lakes, rivers and floodlands, } \\
\text { riverine alluvia, mid-forest wetlands }(\mathrm{P})\end{array}$ & SN & ho & ASN \\
\hline $\begin{array}{l}\text { Epilobium ciliatum Raf. (E. } \\
\text { adenocaulon Hausskn.) }\end{array}$ & N Am & $\begin{array}{l}\text { fallow lands, dump sites, waysides, water } \\
\text { body edges, shrubs, forests, near houses, } \\
\text { (Al, M-A, Ph, St) }\end{array}$ & ASN & ho & ASN \\
\hline Erigeron annuus (L.) Pers. & N Am & $\begin{array}{l}\text { dry waysides, tree-lines, wastelands, fallow } \\
\text { lands, rubble sites, dry meadows (Ar, M-A) }\end{array}$ & AS & he & AS \\
\hline $\begin{array}{l}\text { Fraxinus pennsylvanica } \\
\text { Marshall (F. pubescens Lam.) }\end{array}$ & N Am & forests, shrubs, tree-lines (Q-F) & $\mathrm{N}$ & ho & ASN \\
\hline Helianthus tuberosus L. & N Am & $\begin{array}{l}\text { near houses, waysides, along fences, } \\
\text { shrubs, rubble sites, wastelands, overgrown } \\
\text { meadows, fringes of small mid-field water } \\
\text { body (Ar, M-A) }\end{array}$ & AS & he & ASN \\
\hline $\begin{array}{l}\text { Heracleum mantegazzianum } \\
\text { Sommier \& Levier }\end{array}$ & $\begin{array}{l}\text { Asia } \\
\text { (Caucasus) }\end{array}$ & $\begin{array}{l}\text { roadsides, wastelands, railway } \\
\text { embankments, water body edges (Ar, Sa) }\end{array}$ & AS & he & ASN \\
\hline $\begin{array}{l}\text { Heracleum sosnowskyi } \\
\text { Manden. }\end{array}$ & $\begin{array}{l}\text { Asia } \\
\text { (Caucasus) }\end{array}$ & $\begin{array}{l}\text { wastelands, fallow lands, forest fringes, } \\
\text { water-logged shrubs, ditches, water body } \\
\text { shores, waysides, balks, mid-field tree } \\
\text { plantings (Ar, Sa) }\end{array}$ & ASN & ho & ASN \\
\hline Impatiens capensis Meerb. & N Am & $\begin{array}{l}\text { riparian forests, tall herb fringe } \\
\text { communities of riparian forests, rushes }(\mathrm{Ph} \text {, } \\
\mathrm{Q}-\mathrm{F})\end{array}$ & $\mathrm{N}$ & ho & $\mathrm{N}$ \\
\hline $\begin{array}{l}\text { Impatiens glandulifera Royle } \\
\text { (I. roylei Walp.) }\end{array}$ & $\begin{array}{l}\text { C Asia } \\
\text { (Himalaya) }\end{array}$ & $\begin{array}{l}\text { lake shores, watercourse and wetland } \\
\text { banks, rubble sites, water-logged meadows, } \\
\text { shrubs, riparian forests, tall herb fringe } \\
\text { communities of riparian forests, along } \\
\text { fences, waysides ( } \mathrm{Ar}, \mathrm{Ph}, \mathrm{Q}-\mathrm{F}, \mathrm{Sa})\end{array}$ & ASN & ho & ASN \\
\hline Impatiens parviflora $\mathrm{DC}$. & C \& E Asia & $\begin{array}{l}\text { deciduous and mixed forests, forest crops, } \\
\text { water-logged shrubs, along houses, forest } \\
\text { waysides, cemeteries, dump sites, parks, } \\
\text { railway tracks (Ar, Q-F) }\end{array}$ & ASN & ho & ASN \\
\hline Juglans regia $\mathrm{L}$. & Asia & $\begin{array}{l}\text { meadows, wastelands, near houses, rural } \\
\text { parks, shrub and tree plantings (Ar, M-A) }\end{array}$ & AS & he & ASN \\
\hline Lolium multiflorum Lam. & $\begin{array}{l}\text { SW Eur, SW } \\
\text { Asia, N Afr }\end{array}$ & $\begin{array}{l}\text { meadows, balks, pasture lands, waysides } \\
\text { (M-A, St) }\end{array}$ & AS & he & AS \\
\hline
\end{tabular}




\begin{tabular}{|c|c|c|c|c|c|}
\hline Species & Area of origin & $\begin{array}{l}\text { Habitats and vegetation (syntaxonomic } \\
\text { class) colonized in Western Pomerania }\end{array}$ & $\begin{array}{l}\text { Type of } \\
\text { habitat in } \\
\text { Western } \\
\text { Pomerania }\end{array}$ & $\begin{array}{l}\text { Geographic- } \\
\text { historical } \\
\text { group in } \\
\text { Western } \\
\text { Pomerania }\end{array}$ & $\begin{array}{l}\text { Type of } \\
\text { habitat } \\
\text { in } \\
\text { Poland }\end{array}$ \\
\hline Lupinus polyphyllus Lindl. & N Am & $\begin{array}{l}\text { wastelands, grasslands, forest fringes, tree } \\
\text { clearings, waysides, along fences, fresh } \\
\text { meadows, along houses (Ar, M-A) }\end{array}$ & AS & he & ASN \\
\hline $\begin{array}{l}\text { Lycium barbarum L. (L. } \\
\text { halimifolium Mill., L. vulgare } \\
\text { Dunal) }\end{array}$ & $\begin{array}{l}\text { SE Eur, E } \\
\text { Asia }\end{array}$ & $\begin{array}{l}\text { waysides, along fences, shrubs, } \\
\text { xerothermic grasslands, robinia tree } \\
\text { plantings, parks (Ar) }\end{array}$ & A & he & ASN \\
\hline $\begin{array}{l}\text { Padus serotina (Ehrh.) } \\
\text { Borkh. }\end{array}$ & $\mathrm{N} \& \mathrm{C} A \mathrm{~m}$ & $\begin{array}{l}\text { deciduous, mixed and pine forests, forest } \\
\text { fringes, shrubs, parks, postindustrial areas, } \\
\text { heath-lands (N-C, Q-F, T-G, V-P) }\end{array}$ & ASN & ho & ASN \\
\hline Quercus rubra L. & N Am & $\begin{array}{l}\text { deciduous, mixed and pine forests, shrubs, } \\
\text { pine tree-stands, waysides, rural parks }(\mathrm{Q}, \\
\text { V-P) }\end{array}$ & ASN & ho & $\mathrm{N}$ \\
\hline $\begin{array}{l}\text { Reynoutria japonica Houtt. } \\
\text { (Polygonum cuspidatum } \\
\text { Siebold \& Zucc.) }\end{array}$ & E Asia & $\begin{array}{l}\text { shrubs, waysides, along fences, ditches and } \\
\text { rivers, parks, dump sites (Ar, Sa) }\end{array}$ & AS & he & ASN \\
\hline $\begin{array}{l}\text { Reynoutria sachalinensis (F. } \\
\text { Schmidt) Nakai (Polygonum } \\
\text { sachalinense F. Schmidt) }\end{array}$ & E Asia & $\begin{array}{l}\text { shrubs, waysides, along fences, ditches and } \\
\text { rivers, dump sites (Ar) }\end{array}$ & AS & he & ASN \\
\hline Robinia pseudoacacia L. & N Am & $\begin{array}{l}\text { Robinia (pure stands), deciduous and } \\
\text { mixed forests, termophilous grasslands and } \\
\text { shrubs, waysides, tree-lines, heathlands, } \\
\text { tree clearings, lake shores, mid-field tree } \\
\text { plantings, parks (E, N-C, R-P, Q-F) }\end{array}$ & ASN & ho & ASN \\
\hline Rosa rugosa Thunb. & E Asia & $\begin{array}{l}\text { waysides, shrubs, near houses, railway } \\
\text { areas, parks, seaside dunes (Ar, K-C) }\end{array}$ & ASN & ho & ASN \\
\hline Salix acutifolia Willd. & E Eur, C Asia & seaside dunes (Am) & $\mathrm{N}$ & ho & ASN \\
\hline Solidago canadensis L. & N Am & $\begin{array}{l}\text { wastelands, waysides, balks and fallow } \\
\text { lands, water-logged shrubs, dry meadows, } \\
\text { railway tracks (Ar, M-A) }\end{array}$ & AS & he & ASN \\
\hline $\begin{array}{l}\text { Solidago gigantea Aiton }(S . \\
\text { serotina Aiton) }\end{array}$ & N Am & $\begin{array}{l}\text { wastelands, waysides, water-logged tall } \\
\text { herb communities, meadows, river banks, } \\
\text { lake and pond shores (Ar, M-A) }\end{array}$ & AS & he & ASN \\
\hline $\begin{array}{l}\text { Xanthium albinum (Widder) } \\
\text { H. Scholz (X. riparium Itzigs. } \\
\text { \& Hertsch) }\end{array}$ & N Am & $\begin{array}{l}\text { riverine alluvia, water-logged meadows, } \\
\text { waysides, fields (Ar, St, M-A) }\end{array}$ & AS & ho & AS \\
\hline
\end{tabular}

Explanations: area of origin (after Tokarska-Guzik et al. 2013), Afr - Africa, Am - America, Eur - Europe, Med - Mediterranean Area; type of vegetation colonized in NW Poland (according to Matuszkiewicz 2001 and Zając \& Zając 2009), Al - Alnetea glutinosae, Am - Ammophiletea, Ar - Artemisietea vulgaris, B - Bidentetea tripartiti, E - Epilobietea angustifolii, K-C - Koelerio-Corynephoretea, L - Lemnetea, M-A - Molinio-Arrhenatheretea, N-C - NardoCallunetea, $\mathrm{Ph}$ - Phragmitetea, P - Potametea, Q - Quercetea robori-petraeae, Q-F - Querco-Fagetea, R-P - Rhamno-Prunetea, Sa - Salicetea purpureae, $\mathrm{St}$ - Stellarietea mediae, S-C - Scheuchzerio-Caricetea nigrae, T-G - Trifolio-Geranietea, V-P - Vaccinio-Piceetea; geographic-historical groups in Western Pomerania, arch - archaeophyte, ep - epekophyte (=neophyte migrating into antrophogenic habitas), ho - holoagriophyte (=neophyte migrating into semi-natural habitats), he - hemiagriophyte (=neophyte migrating into natural habitats); type of habitats in Poland (after Tokarska-Guzik et al. 2013), A - anthropogenic habitats, $\mathrm{S}$ - semi-natural communities, $\mathrm{N}$ - natural communities

or collection; source of data, possible comments or remarks. The basis for graphical representation of the distribution of species is a map automatically generated on the basis of information comprised in the database, having a grid with the basic cartogram unit of $2.5 \times 2.5$ $\mathrm{km}$. The filled cartogram unit indicates that a species is present in a given area and is treated as a single site, irrespective of the number of its locations within a marked field.

\section{Results and discussion}

A tentative list of invasive and potentially invasive species comprises 32 and 23 taxa, respectively (Tables 1-2, Appendix 1). Among hemiagriophytes, the most common and troublesome ones are Conyza canadensis, Erigeron annuus, Lolium multiflorum, Lupinus polyphyllus, Solidago canadensis, S. gigantea. The species which received the holoagriophyte status in many parts 
Table 2. A tentative list of potentially invasive vascular plant species in Western Pomerania (NW Poland)

\begin{tabular}{|c|c|c|c|c|c|}
\hline Species & $\begin{array}{l}\text { Area of } \\
\text { origin }\end{array}$ & $\begin{array}{l}\text { Habitats and vegetation (syntaxonomic } \\
\text { class) colonized in Western Pomerania }\end{array}$ & $\begin{array}{l}\text { Type of } \\
\text { habitat in } \\
\text { Western } \\
\text { Pomerania }\end{array}$ & $\begin{array}{l}\text { Geographic- } \\
\text { historical group } \\
\text { in Western } \\
\text { Pomerania }\end{array}$ & $\begin{array}{l}\text { Type of } \\
\text { habitat in } \\
\text { Poland }\end{array}$ \\
\hline Ambrosia psilostachya DC. & $\mathrm{N}$ Am & waysides, sand grasslands (Ar, K-C) & AS & he & A \\
\hline $\begin{array}{l}\text { Amelanchier spicata } \\
\text { (Lam.) K. Koch }\end{array}$ & $\mathrm{N} A m$ & $\begin{array}{l}\text { acid mixed, oak and pine forests (V-P, } \\
\text { Q-F) }\end{array}$ & $\mathrm{N}$ & ho & $\mathrm{SN}$ \\
\hline Aster novae-angliae L. & N Am & river banks, waysides (Ar) & A & ep & AS \\
\hline Aster novi-belgii L. & $\mathrm{N}$ Am & $\begin{array}{l}\text { shrubs, tall herb communities, tree- } \\
\text { lines, waysides, pond shores (Ar) }\end{array}$ & A & ep & AS \\
\hline Aster $\times$ salignus Willd. & $\mathrm{N}$ Am & river banks, waysides (Ar) & A & ep & AS \\
\hline $\begin{array}{l}\text { Bromus carinatus Hook. } \\
\text { \& Arn. }\end{array}$ & N Am & $\begin{array}{l}\text { wastelands, waysides, along fences, } \\
\text { near houses, shrubs, meadows, parks } \\
\text { (Ar, St, M-A) }\end{array}$ & AS & he & ASN \\
\hline Bunias orientalis L. & $\begin{array}{l}\text { SE Eur, W } \\
\text { Asia }\end{array}$ & $\begin{array}{l}\text { fresh meadows, wastelands, waysides, } \\
\text { sandy idle lands, railway tracks (Ar, } \\
\text { M-A) }\end{array}$ & AS & he & AS \\
\hline $\begin{array}{l}\text { Cerasus mahaleb (L.) Mill. } \\
\text { (Prunus mahaleb L.) }\end{array}$ & $\begin{array}{l}\text { S Eur, C } \\
\text { Asia, SW } \\
\text { Afr }\end{array}$ & $\begin{array}{l}\text { termophilous and psammophilous } \\
\text { shrubs and grassland (R-P) }\end{array}$ & $\mathrm{S}$ & he & ASN \\
\hline $\begin{array}{l}\text { Elodea nuttallii (Planch.) } \\
\text { H. St. John }\end{array}$ & $\mathrm{N}$ Am & rivers $(\mathrm{P})$ & $\mathrm{N}$ & ho & AN \\
\hline $\begin{array}{l}\text { Juncus tenuis Willd. ( } J . \\
\text { macer A. Gray) }\end{array}$ & $\mathrm{N}$ Am & $\begin{array}{l}\text { forest paths and waysides, meadows, } \\
\text { pasture lands, roadsides, lake and small } \\
\text { water body shores (M-A, St) }\end{array}$ & AS & he & AS \\
\hline $\begin{array}{l}\text { Lactuca tatarica (L.) C. A. } \\
\text { Mey. }\end{array}$ & $\begin{array}{l}\text { SE Eur, W } \\
\text { Asia }\end{array}$ & seaside dunes (Am) & $\mathrm{N}$ & ho & \\
\hline $\begin{array}{l}\text { Larix kaempferi (Lamb.) } \\
\text { Carričre }\end{array}$ & E Asia & coniferous forests (V-P) & $\mathrm{N}$ & ho & $\mathrm{N}$ \\
\hline Lemna turionifera Landolt & $\mathrm{N} A m$ & lakes $(\mathrm{L})$ & $\mathrm{N}$ & ho & $\mathrm{SN}$ \\
\hline $\begin{array}{l}\text { Mahonia aquifolium } \\
\text { (Pursh) Nutt. }\end{array}$ & N Am & mixed and coniferous forests (Q-F, V-P) & $\mathrm{N}$ & ho & ASN \\
\hline Mimulus guttatus DC. & $\mathrm{N} A m$ & wet meadows (M-A) & $\mathrm{S}$ & he & $\mathrm{SN}$ \\
\hline $\begin{array}{l}\text { Parthenocissus inserta (A. } \\
\text { Kern.) Fritsch (P. inserata } \\
\text { (A. Kern.) Fritsch } \\
\text { P. vitacea (Knerr) Hitchc.) }\end{array}$ & $\mathrm{N}$ Am & $\begin{array}{l}\text { pine and mixed forests, shrubs, } \\
\text { waysides, along houses, railway } \\
\text { embankments (Ar, Q-F, St, V-P) }\end{array}$ & $\mathrm{AN}$ & ho & ASN \\
\hline $\begin{array}{l}\text { Reynoutria } \times \text { bohemica } \\
\text { Chrtek \& Chrtková }\end{array}$ & anthrop & $\begin{array}{l}\text { waysides, near houses, railway } \\
\text { embankments, along ditches and rivers, } \\
\text { dump sites (Ar) }\end{array}$ & A & ep & ASN \\
\hline Rubus laciniatus Willd. & anthrop & $\begin{array}{l}\text { deciduous, mixed and pine forests (Q-F, } \\
\text { V-P) }\end{array}$ & $\mathrm{N}$ & ho & ASN \\
\hline Rudbeckia hirta L. & $\mathrm{N} A m$ & waysides, near houses (Ar) & A & ep & AS \\
\hline Senecio inaequidens DC. & S Afr & $\begin{array}{l}\text { waysides, track-ways, sandy grasslands } \\
\text { (Ar, K-C) }\end{array}$ & AS & he & A \\
\hline Spiraea tomentosa L. & N Am & $\begin{array}{l}\text { fens and transitional bogs, unused } \\
\text { water-logged meadows, water body } \\
\text { shores, riverine carr, alder carr, } \\
\text { roadsides (Al, M-A, Ph, S-C) }\end{array}$ & $\mathrm{N}$ & ho & ASN \\
\hline Vicia grandiflora Scop. & $\begin{array}{l}\text { S Eur, SW } \\
\text { Asia }\end{array}$ & $\begin{array}{l}\text { waysides, meadows, grasslands, } \\
\text { wastelands, farmlands and fallow lands, } \\
\text { railway tracks (Ar, M-A, St) }\end{array}$ & AS & he & AS \\
\hline
\end{tabular}

Explanations: see Table 1 


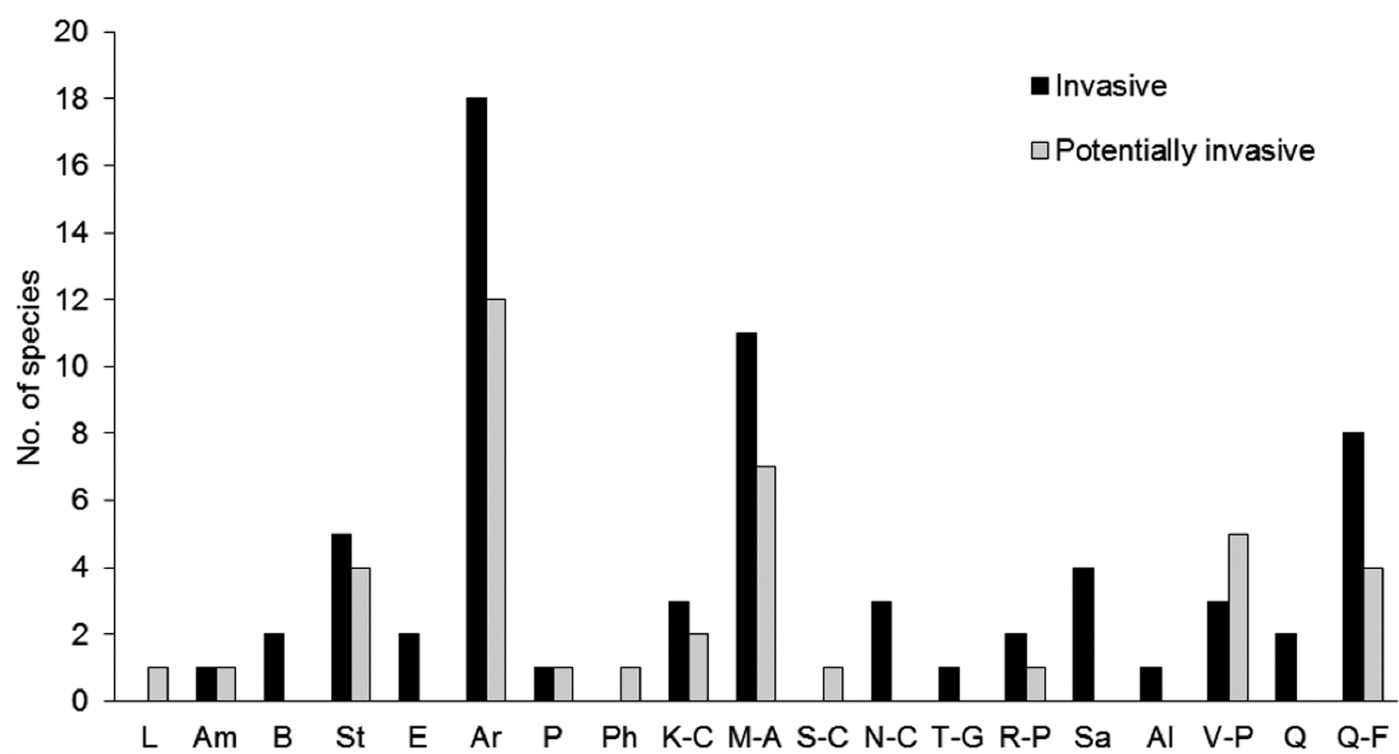

Fig. 2. Participation of invasive and potentially invasive species in the vegetation of Western Pomerania according to phytosociological classes Explanation: see Table 1

of Poland and are downright troublesome invasive species there, such as, for example, Echinocystis lobata or Reynoutria japonica and R. sachalinensis, spread intensely in Western Pomerania and their populations are large in some cases, but they are still quite rare in some areas (e.g. the Myślibórz Lakeland, eastern part of the Drawsko Lakeland). Among holoagriophytes, i.e. the taxa which received the highest naturalisation status, very expansive species, which are successful in land colonisation, like Acer negundo, Bidens frondosa, B. connata, Clematis vitalba, Elodea canadensis, Epilobium ciliatum, Heracleum sosnowskyi, Impatiens glandulifera, I. parviflora, Padus serotina, Quercus rubra and Robinia pseudoacacia, should be given particular attention. Acer negundo and last three tree species spread quickly; they have been planted by foresters in many areas of Western Pomerania as a biocenotic admixture in conifer and mixed forests, like non-invasive but very frequent in the Pomeranian forests non-native species: Aesculus hippocastanum, Alnus incana and Picea abies. Larix kaempferi and Amelanchier spicata, planted, established and spread in the area under study, which are likely to become potentially invasive, should also be given attention. In many places, Robinia pseudoacacia forms pure stands with a very poor undergrowth, usually built almost exclusively by nitrophilous apophytes and kenophytes (neophytes). Rosa rugosa and Salix acutifolia, the species commonly planted by maritime authorities, are highly invasive on the whole coast, form extensive shrubs in many places and overgrow white and grey dunes. A holoagriophyte rapidly spreading at present is Fraxinus pennsylvanica, which is frequent in the Lower Odra valley but also on the coast. It spreads from park and roadside plantings, probably is also undistinguished and erroneously identified in the nursery material, from where it could get into forests. Impatiens parviflora has been the most successful in the colonisation of Western Pomerania and is present in plantings in the entire region; this also refers to I. glandulifera, very intensely spreading at present, mainly along watercourses, and I. capensis, frequent along the Szczecin Lagoon and the Dąbie Lake shores (observed for the first time near Trzebież in 1987; Pawlaczyk \& Adamowski 1991). The spreading of Lactuca tatarica along the Baltic Sea coast from the west, which occurs on the Wolin Island and around Dziwnów on white dunes, is worth mentioning. It has been reported as an invasive neophyte from the North-West German coast (Berg \& Barth 2008). These authors place Calystegia pulchra, C. silvatica and Cotula coronopifolia (so far not reported on the Western Pomeranian coast) and Rosa rugosa (mentioned above) among invasive species associated with the seashore in Germany, too.

Many taxa considered invasive or potentially invasive in the southern Poland (Tokarska-Guzik et al. 2012) are found in Western Pomerania on single sites only and are not invasive at present (e.g. Ailanthus altissima, Ambrosia artemisiifolia, Rudbeckia lacinata, Rumex confertus, Telekia speciosa, Veronica peregrina). Spiraea tomentosa has not been observed yet, except for the locations in the Drawsko Forest (Dajdok \& Pawlaczyk 2009); on the other hand, there are known locations with hairy hybrids overgrowing small water bodies and bog formations. The occurrence of Reynoutria $\times$ bohemica requires further study; this species has been observed in Szczecin but is probably more widespread (presence 
$\mathbf{a}$

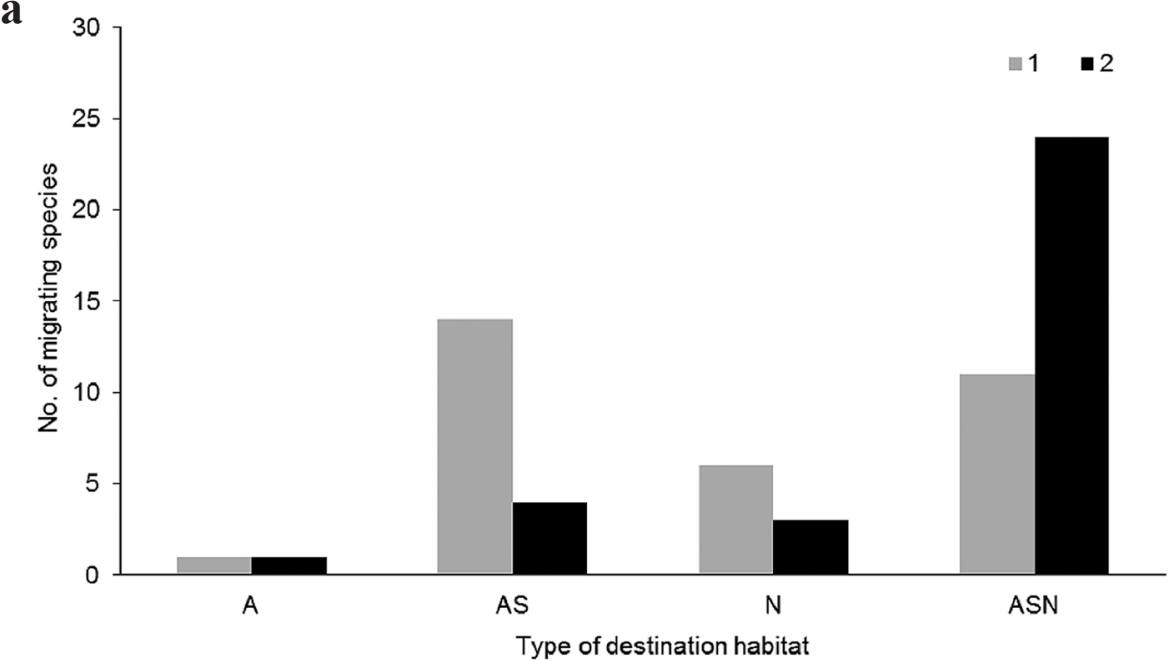

b

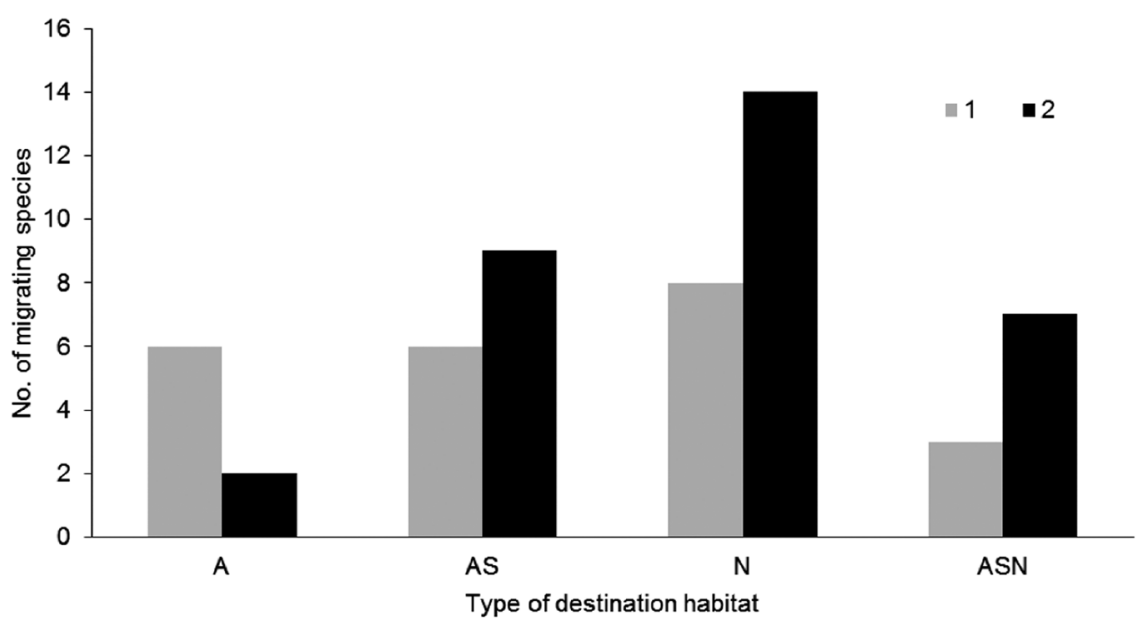

Fig. 3. Number of invasive (a) and potentially invasive species (b) migrating into different types of habitats of Western Pomerania compared to their status in Poland (after Tokarska-Guzik et al. 2013)

Explanations: A - anthropogenic, S - semi-natural, N - natural; 1 - Western Pomerania, 2 - Poland

of parental taxa). Digitalis purpurea is a species already widespread in our region in different, mainly coniferous, forest complexes; it is associated with forest gaps in poor habitats and is usually found on forest roadsides and near tree-clearings. It is moderately numerous in these locations, spreads but has not posed a significant threat for native flora and ecosystem functioning yet. Mahonia aquifolium, which is quite frequent and rebuilding in forests, for instance in the Myślibórz Lakeland, behaves similarly but its occurrence has not been well recognised yet.

Among the invasive and potentially invasive species of NW Poland, most taxa penetrate the plant communities of the class Artemisietea and MolinioArrhenatheretea, followed by Querco-Fagetea, Vaccinio-Piceetea, Stellarietea mediae, Salicetea purpurae and Koelerio-Corynophoretea (Fig. 2). Summing up, the analysed species occur in plant communities of 17 phytosociological classes (more than half of them are of totally natural character). The number of invasive species in Western Pomerania occurring exclusively in semi-natural or natural habitats is twice as high when compared to the situation of these species in Poland; on the contrary, the number of species inhabiting anthropogenic, semi-natural and natural habitats is two times lower (Fig. 3a), while that of holoagriophytes and hemiagriophytes is $56.3 \%$ and $43.7 \%$, respectively (Table 1). In the case of potentially invasive species (Fig. 3b), a comparison of the habitats occupied in Western Pomerania and those on the whole territory of Poland shows that they penetrate anthropogenic sites in the area under study more frequently, although this is probably an artefact derived from preliminary findings only. According to the geographic-historical classification, $43.5 \%$ of these taxa are holoagriophytes, $34.8 \%$ are hemiagriophytes, and $21.7 \%$ are epecophytes (Table 2).

When comparing the results of studies on the flora of three areas (Myślibórz Lakeland, the southern part of the Nowogard Plain and the eastern part of the Drawsko 
A

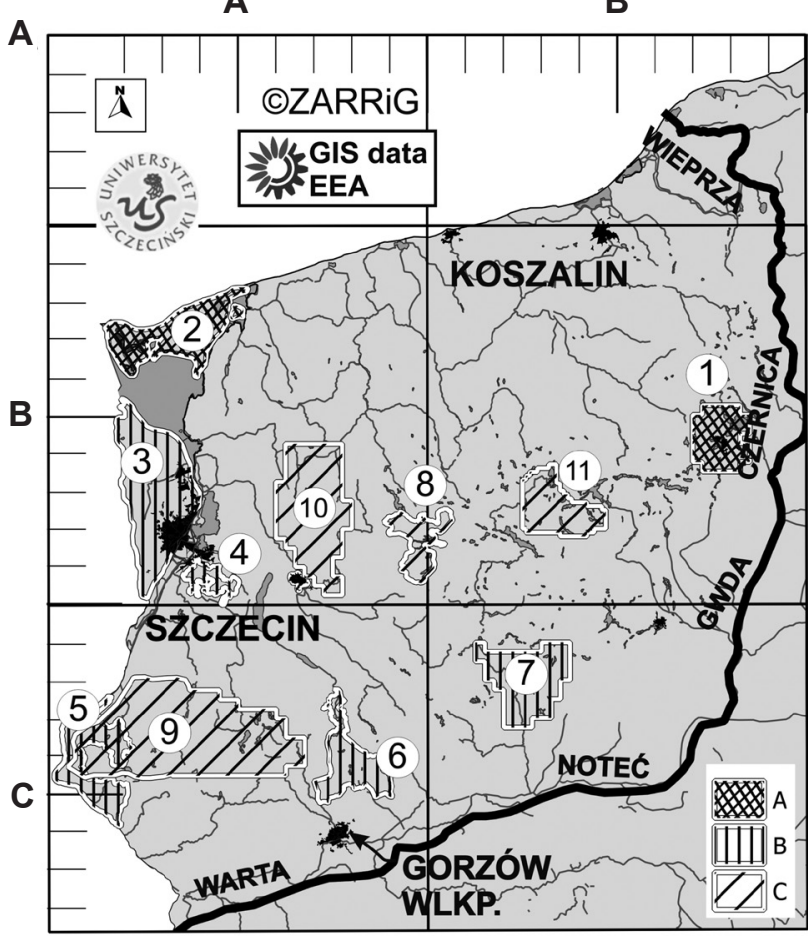

Fig. 4. Regions with the complete vascular flora distribution maps made

Explanations: A - in 2006-2013 (1 - Żukowski 1960, 2 - Piotrowska 1966), B - in the years 1993-2002 (3 - Zając et al. 1993, 4 - Ziarnek 2002 mscr., 5 - Stepień 2004 mscr., 6 - Myśliwy 2003 mscr., 7 - Kujawa-Pawlaczyk 1997 mscr.); C - in the years 2006-2013 (8 - Więclaw 2006, 9 - Startek 2013 mscr., B. Kurnicki unpubl. from the years 2013 and 2014, 10 - Konopska 2013 mscr, 11 - Umiastowska 2012 mscr.)

District), situated in different parts of this region, obtained in recent years, it seems that, in the case of some invasive and potentially invasive species, a decrease may be observed in the number of their locations from the west to the east (e.g. for Acer negundo, Bromus cari- natus, Clematis vitalba, Helianthus tuberosus, Lycium barbarum, Reynoutria japonica, Rosa rugosa, Vicia grandiflora). Distribution patterns for some species (e.g. for or Xanthium albinum) are indicative of a likely major role of the Odra River valley in the spreading of invasive species.

Among the potentially invasive species in NW Poland (Table 2), only five species (Aster novae-angliae, A. novi-belgii, A. $\times$ salignus, Reynoutria $\times$ bohemica and Rudbeckia hirta) penetrate ruderal and segetal habitats; the other ones inhabit semi-natural and natural habitats as well. This may indicate that they can receive the status of invasive species in the near future as they continue to spread and enlarge their population.

Distribution maps for particular species, like the lists of invasive (Table 1) and potentially invasive species (Table 2) provided in this paper, are tentative. It should be kept in mind that the area of North-West Poland is poorly examined in terms of its flora. Only for some areas, maps of distribution of vascular plant floras have been prepared in recent years using the method of uniform test areas - cartogram method (Fig. 4). Therefore, the species distribution presented in these areas only is fully reliable. Nevertheless, the maps illustrate colonisation trends and directions and, moreover, have been so far the only attempt to synthesise this problem in NW Poland.

Acknowledgements. The authors wish to express their gratitude to the editors of the Distribution Atlas of Vascular Plants in Poland, Prof. Dr Maria Zając and Prof. Dr Adam Zając, for access to the ATPOL database, and to everybody who allowed us access to unpublished floristic data, particularly, to Dr Wojciech Kowalski, Dr Zbigniew Sobisz and Dr Magdalena Ziarnek. The authors express also their gratitude to the anonymous reviewer for detailed comments, which greatly improved the manuscript.

\section{References}

Berg C. \& Barth H. 2008. Does the inner Baltic Sea coast provide a habitat for invasive neophytes? In: W. RABitsch, F. Essl \& F. KLINGENSTEIN (eds.). Biological Invasions - from Ecology to Conservation. NEOBIOTA 7: 218-223.

Bettinger A., Buttler K. P., Caspari S., Klotz J., May R. \& Metzing D. 2013. Verbreitungsatlas der Farn- und Blütenpflanzen Deutschlands. 912 pp. Netzwerk Phytodiversität Deutschlands, Reden, Bonn

DAJDOK Z. \& PAWLACZYK P. 2009. Inwazyjne gatunki roślin ekosystemów mokradłowych Polski. 85 pp. Wyd. Klubu Przyrodników, Świebodzin.

Fukarek F. \& Henker H. 2006. Flora von MecklenburgVorpommern. 428 pp. Weissdornverlag, Jena.
HultÉN E. \& Fries M. 1986. Atlas of North European vascular plants. North of the Tropic of Cancer. I-III. xvi+1172 pp. Koeltz Scientific Books, Königstein.

JALAS J. \& SuOMinEN J. (eds.). 1972-1994. Atlas Florae Europaeae. Distribution of Vascular Plants in Europe. Vol. 1-10. The Committee for Mapping the Flora of Europe \& Societas Biologica Fennica Vanamo, Helsinki.

Jalas J., Suominen J. \& Lampinen R. (eds.). 1996. Atlas Florae Europaeae. Distribution of Vascular Plants in Europe. 11. Cruciferae (Ricotia to Raphanus). 310 pp. The Committee for Mapping the Flora of Europe \& Societas Biologica Fennica Vanamo, Helsinki. Maps 2434-2927.

Jalas J., Suominen J., Lampinen R. \& Kurtto A. (eds.). 1999. Atlas Florae Europaeae. Distribution of Vascular 
Plants in Europe. 12. Resedeaceae to Platanaceae. 250 pp. The Committee for Mapping the Flora of Europe \& Societas Biologica Fennica Vanamo, Helsinki. Maps 2928-3270.

KONOPSKA K. (mscr.). 2013. Problemy fitogeograficzne i flora południowej części Równiny Nowogardzkiej. Ph. D. Thesis, Department of Botany and Nature Conservation, University of Szczecin.

Kujawa-Pawlaczyk J. (mscr.). 1997. Synantropizacja szaty roślinnej Drawieńskiego Parku Narodowego. Ph. D. Thesis, Department of Plant Taxonomy, Adam Mickiewicz University.

Kurtto A., Fröhner S. E. \& Lampinen R. (eds.). 2007. Atlas Florae Europaeae. Distribution of Vascular Plants in Europe. 14. Rosaceae (Alchemilla and Aphanes). 200 pp. The Committee for Mapping the Flora of Europe \& Societas Biologica Fennica Vanamo, Helsinki. Maps 3557-3912.

Kurtto A., Lampinen R. \& JunikKa L. (eds.) 2004. Atlas Florae Europaeae. Distribution of Vascular Plants in Europe. 13. Rosaceae (Spiraea to Fragaria, excl. Rubus). 320 pp. The Committee for Mapping the Flora of Europe \& Societas Biologica Fennica Vanamo, Helsinki. Maps 3271-3556.

Kurtto A., Weber H. E., Lampinen R. \& Sennikov A. N. (eds.). 2010. Atlas Florae Europaeae. Distribution of Vascular Plants in Europe. 15. Rosaceae (Rubus). 320 pp. The Committee for Mapping the Flora of Europe \& Societas Biologica Fennica Vanamo, Helsinki. Maps 3913-4708.

Matuszkiewicz W. 2001. Przewodnik do oznaczania zbiorowisk roślinnych Polski. In: J. B. FALIŃSKI (ed.). Vademecum Geobotanicum 3, 537 pp. Wyd. Nauk. PWN, Warszawa.

Meusel H. \& JäGER E. J. (eds.). 1992. Vergleichende Chorologie der zentraleuropäischen Flora. III. Text ix+333 pp., Karten, Literatur, Register pp. ix+422-688. Gustav Fischer Verlag, Jena-Stuttgart-New York.

Meusel H., Jäger E., Rauschert S. \& Weinert E. 1978. Vergleichende Chorologie der zentraleuropäischen Flora. II. Text xi+418 pp., Karten pp. 259-421. Gustav Fischer Verlag, Jena.

Mirek Z., Piękoś-Mirkowa H., Zając A. \& Zając M. 2002. Flowering plants and pteridophytes of Poland. A checklist. In: Z. MireK (ed.). Biodiversity of Poland, 1, 442 pp. W. Szafer Institute of Botany, Polish Academy of Sciences, Kraków.

Myśliwy M. (mscr.). 2003. Flora roślin naczyniowych Barlinecko-Gorzowskiego Parku Krajobrazowego w warunkach antropogenicznych przemian środowiska przyrodniczego. Ph. D. Thesis, Department of Plant Taxonomy and Phytogeography, University of Szczecin.

PawlaczyK P. \& Adamowski W. 1991. Impatiens capensis (Balsaminaceae) nowy gatunek we florze Polski Fragm. Flor. Geobot. 35: 225-232.

Piotrowska H. 1966. Rośliny naczyniowe wysp Wolina i południowo-wschodniego Uznamu. PTPN, Prace Kom. Biol. 30(4): 1-283.

Popiela A., Łysko A. \& Wieczorek A. 2013a. Western Pomeranian Atlas of Distribution of Vascular Plants and
Fungi (ZARRiG) - project scope and method. Plant Diversity and Evolution 130(3-4): 265-271.

Popiela A., Łysko A. \& Wieczorek A. 2013b. Zachodniopomorski Atlas Rozmieszczenia Roślin Naczyniowych i Grzybów (ZARRiG) - Zakres i Metoda Projektu. In: M. Kuzn \& Nienartowicz A. (eds.). Systemy informacji geograficznej w zarządzaniu obszarami chronionymi - od teorii do praktyki, pp. 161-166, Wydawnictwo UMK, Toruń.

Startek B. (mscr.) 2013. Flora naczyniowa oraz fitogeograficzne zagadnienia środkowej części Pojezierza Myśliborskiego. Ph. D. Thesis, Department of Botany and Nature Conservation, University of Szczecin.

STĘPIEŃ E. (mscr.). 2004. Flora naczyniowa Cedyńskiego Parku Krajobrazowego. Ph. D. Thesis, Department of Plant Taxonomy and Phytogeography, University of Szczecin.

Tokarska-GuZik B., Dajdok Z., Zając M., Zając M., Urbisz Al., Danielewicz W. \& HoŁdyński C. 2012. Rośliny obcego pochodzenia w Polsce ze szczególnym uwzględnieniem gatunków inwazyjnych. 196 pp. Generalna Dyrekcja Ochrony Środowiska, Warszawa.

UmiastowsKa M. (mscr.). 2012. Flora wschodniej części Pojezierza Drawskiego i jej przemiany. Ph. D. Thesis, Department of Botany and Nature Conservation, University of Szczecin.

WiĘCŁAW H. 2006. Flora roślin naczyniowych Ińskiego Parku Krajobrazowego i jej antropogeniczne przeobrażenia. Część I i II. 209 pp., 226 pp. Wyd. Uniw. Szczecińskiego, Szczecin.

ZAJĄC A. 1978. Założenia metodyczne „Atlasu rozmieszczenia roślin naczyniowych w Polsce". Wiad. Bot. 22(3): 145-155.

ZajĄC A., Ciaciura M. \& ZająC M. 1993. Rośliny naczyniowe Zaodrza (na zachód od Szczecina). 151 pp. Rozprawy i Studia Uniwersytetu Szczecińskiego 142 , Szczecin.

Zając A. \& Zając M. (eds.). 2001. Distribution Atlas of Vascular Plants in Poland. xii+714 pp. Edited by Laboratory of Computer Chorology, Institute of Botany, Jagiellonian University, Cracow.

ZAJĄC M. \& ZAJĄC A. 2009. The geographical elements of native flora of Poland. $94 \mathrm{pp}$. Edited by Laboratory of Computer Chorology, Institute of Botany, Jagiellonian University, Kraków.

ZIARNEK M. 2012. Bibliografia botaniczna Pomorza. Rośliny naczyniowe i ochrona przyrody. Publikacje wydane do roku 1945. 300 pp. Sorus, Poznań.

ZIARNEK K. (mscr.) 2002. Dynamika flory roślin naczyniowych Puszczy Bukowej pod Szczecinem. Ph. D. Thesis, Department of Plant Taxonomy, Adam Mickiewicz University.

Ziarnek K., Ziarnek M. \& Wolejko L. 2003. Bibliografia botaniczna Pomorza. Rośliny naczyniowe i ochrona przyrody. Publikacje z lat 1945-2000. 285 pp. Fundacja Akademia Rolnicza w Szczecinie 2010, Szczecin.

ŻUKowski W. 1960. Roślinność naczyniowa okolic Szczecinka. PTPN, Prace Kom. Biol. 22(1): 1-73. 
Appendix 1. Distribution maps of the invasive vascular plant species in Western Pomerania (NW Poland)

A

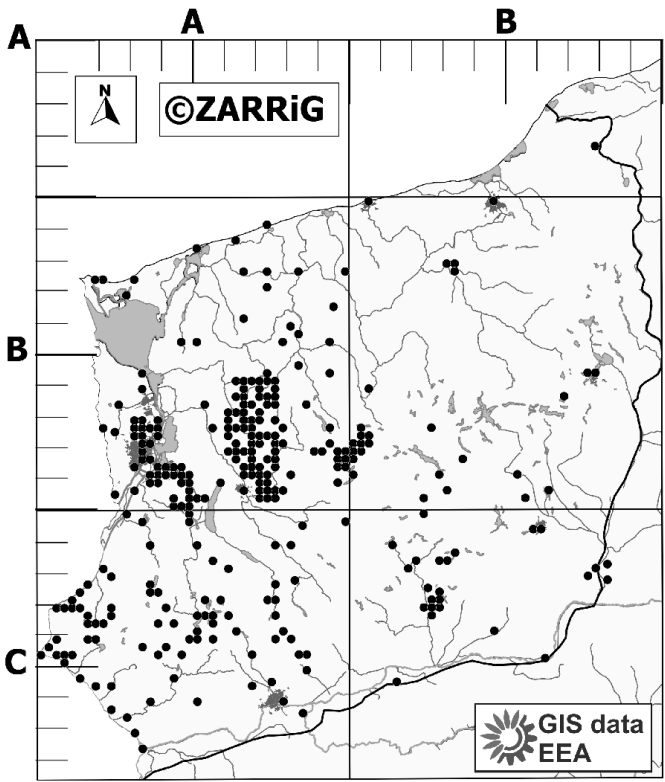

Acer negundo L.

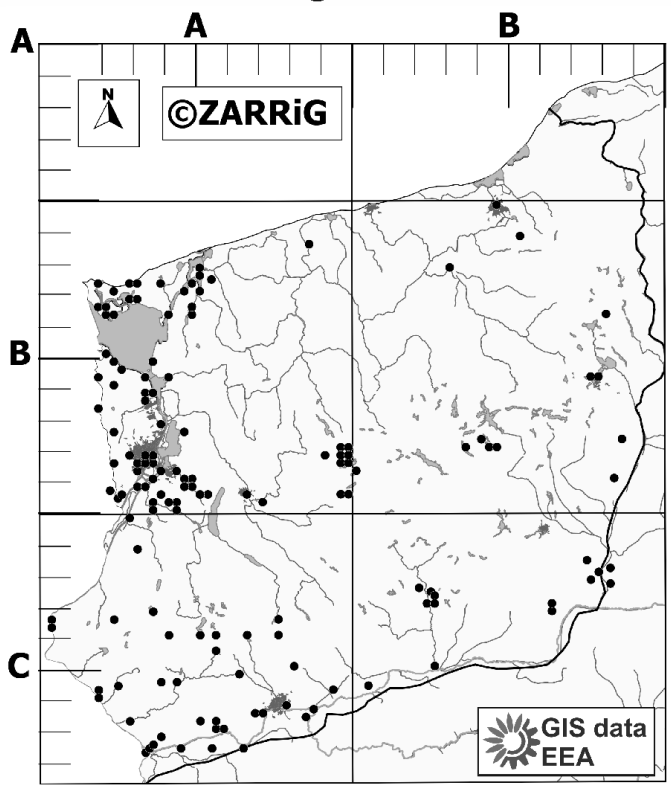

Bidens frondosa $\mathrm{L}$.

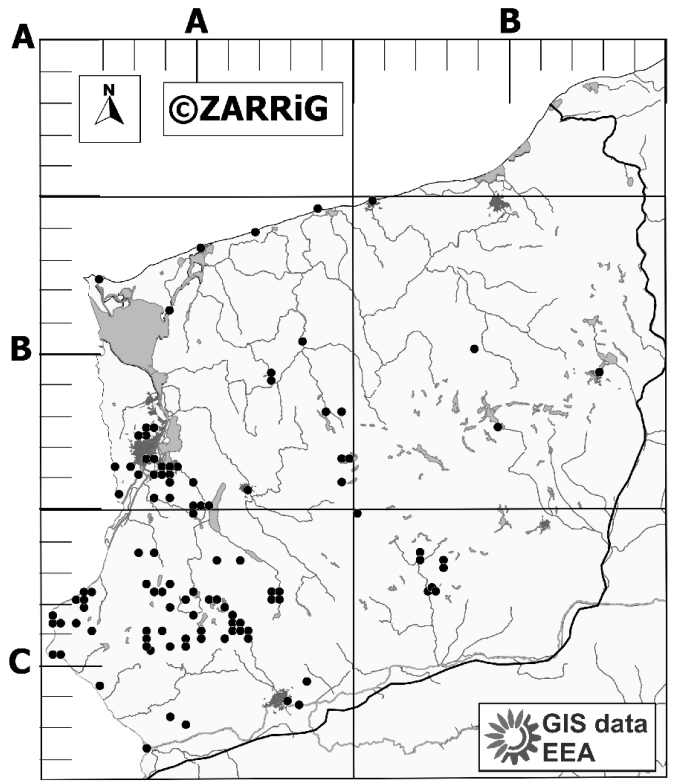

Clematis vitalba $\mathrm{L}$.

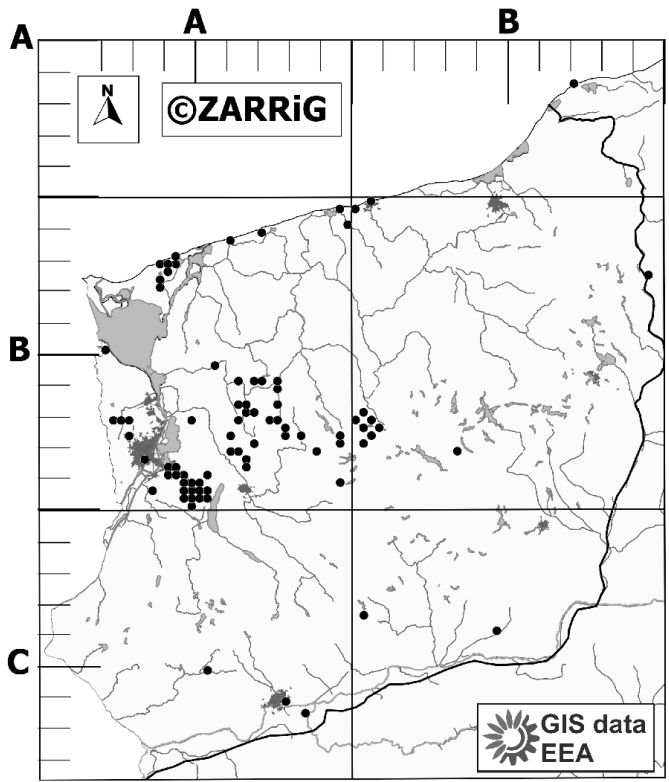

Anthoxanthum aristatum Boiss.

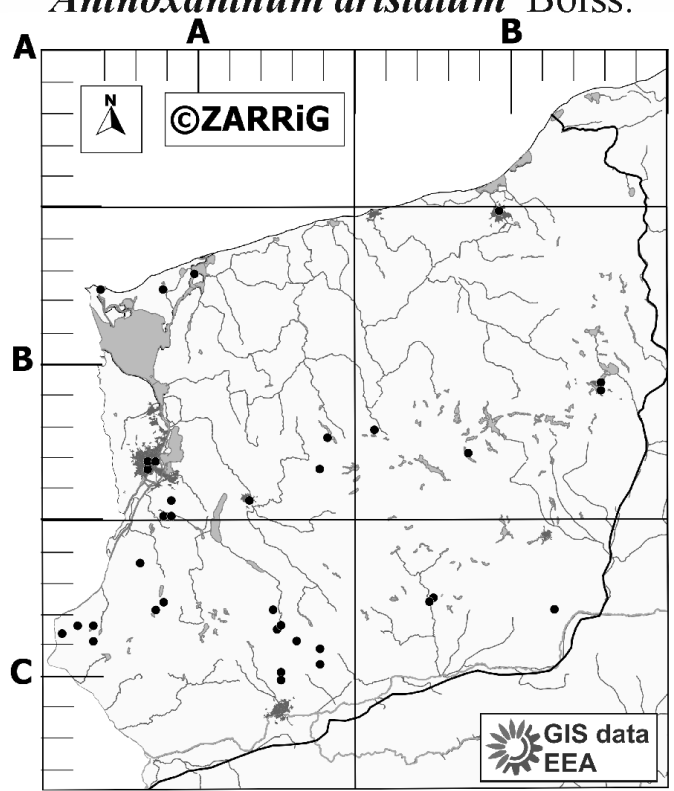

Bidens connata H. L. Mühl

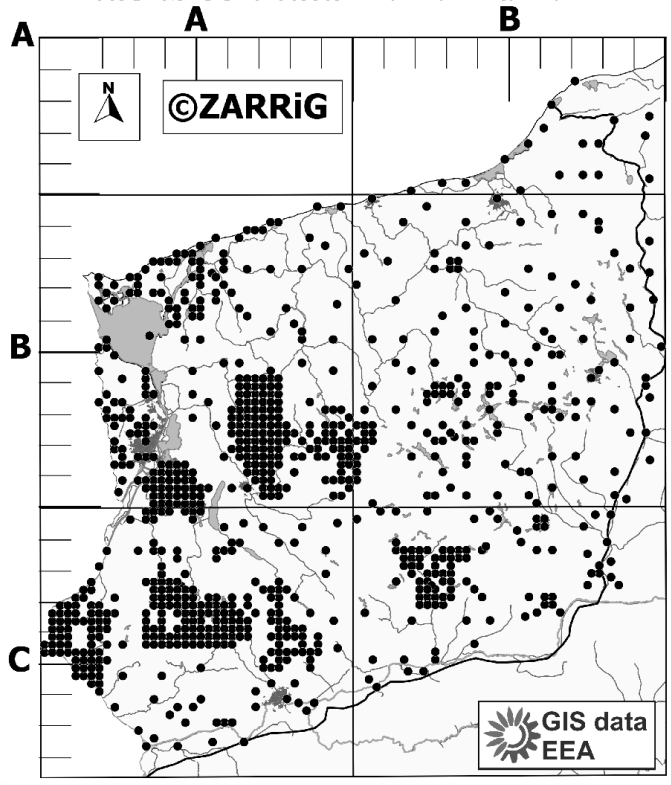

Conyza canadensis (L.) Cronquist 


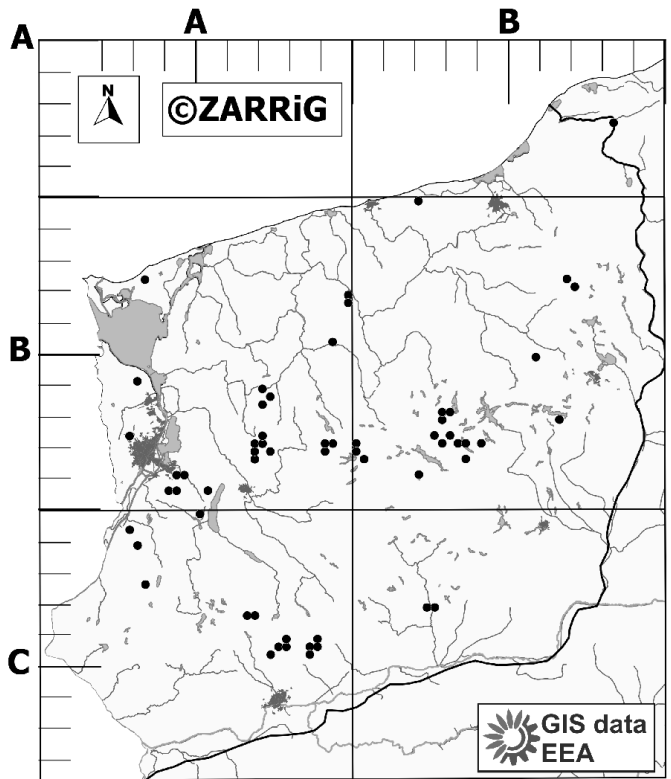

Digtalis purpurea $\mathrm{L}$.

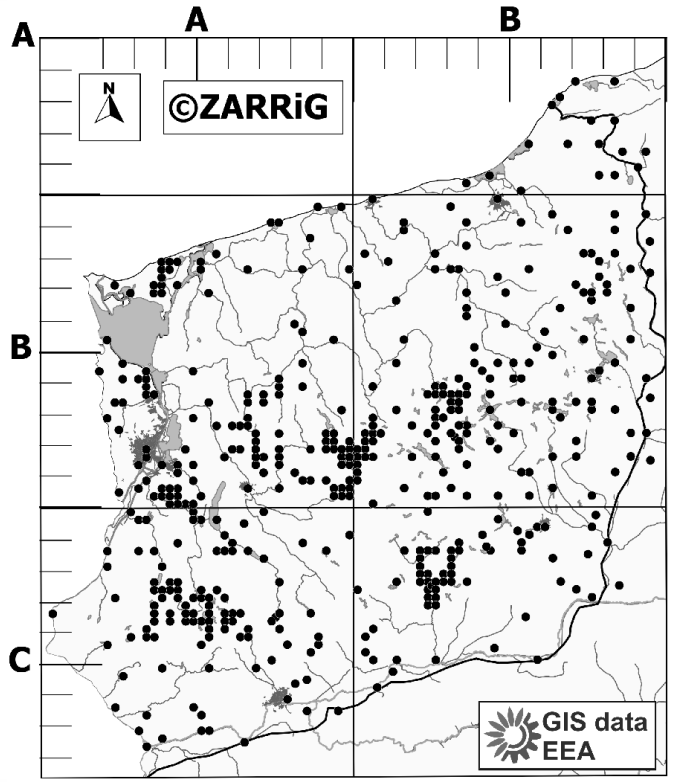

Elodea canadensis Michx.

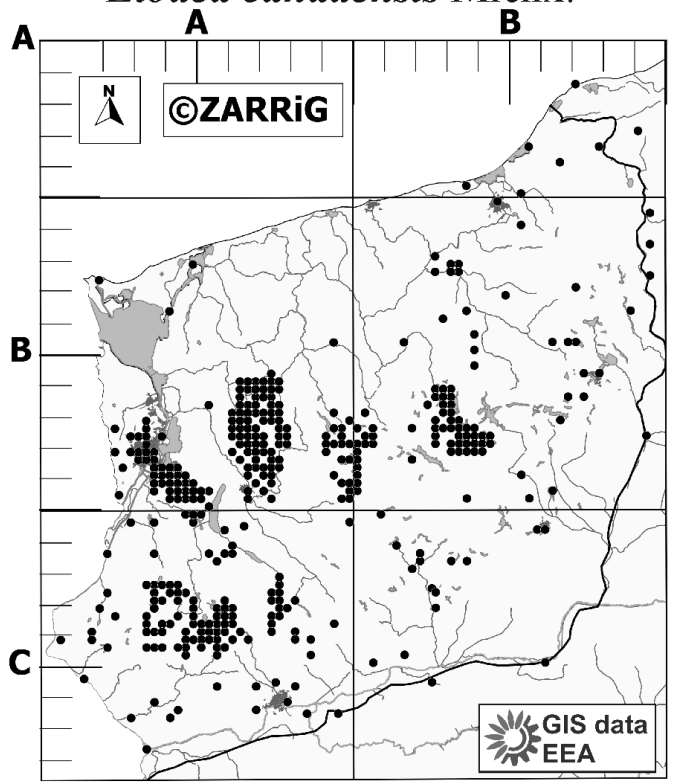

Erigeron annuus (L.) Pers.

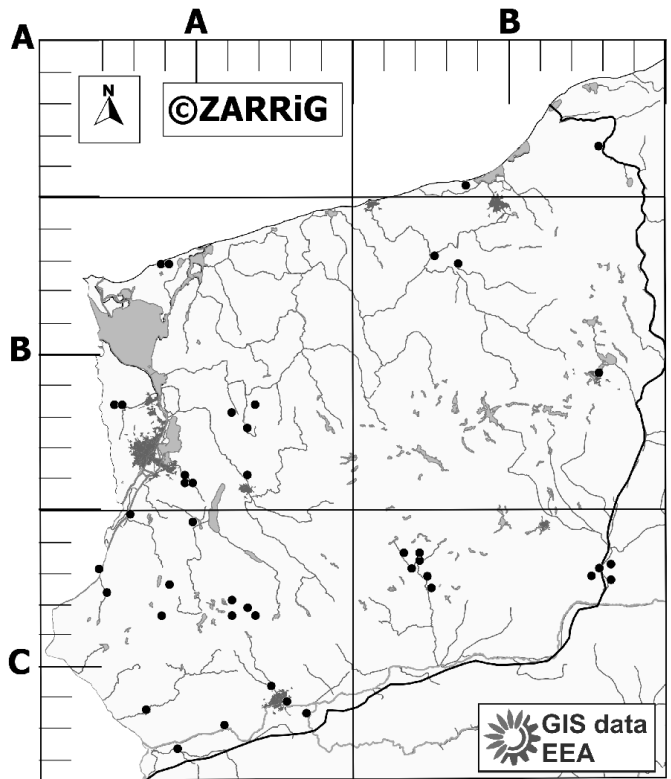

Echinocystis lobata (F. Michx.) Torr. \& A. Gray

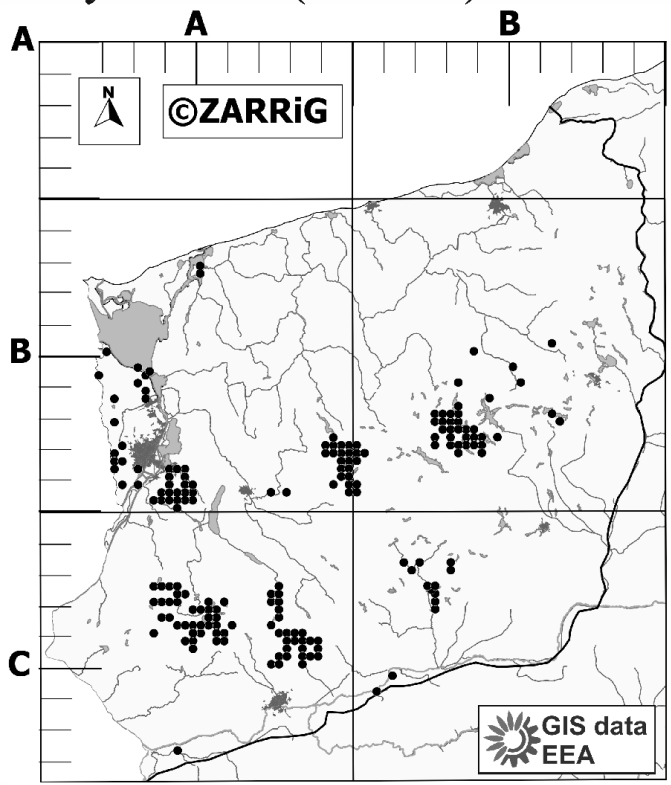

Epilobium ciliatum Raf.

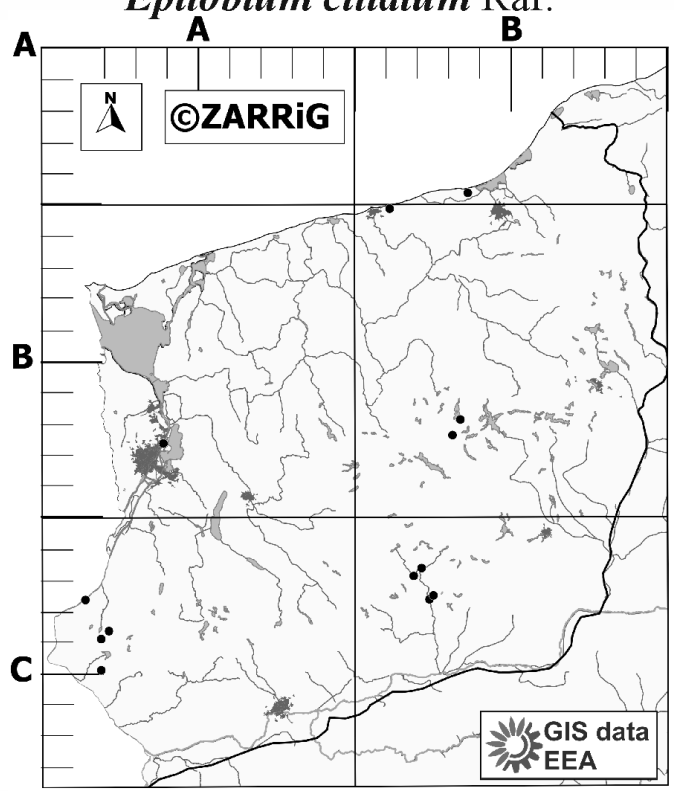

Fraxinus pennsylvanica Marshall 


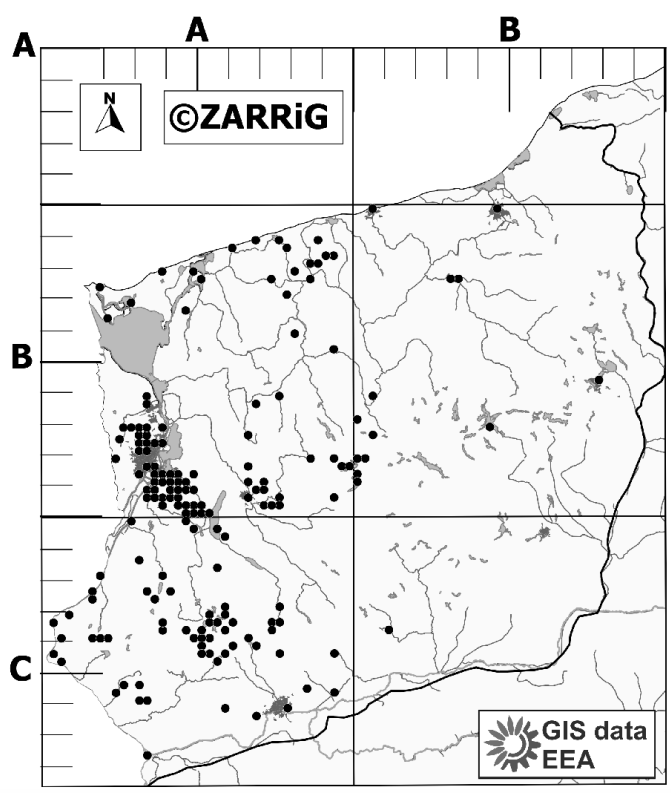

Helianthus tuberosus $\mathrm{L}$.

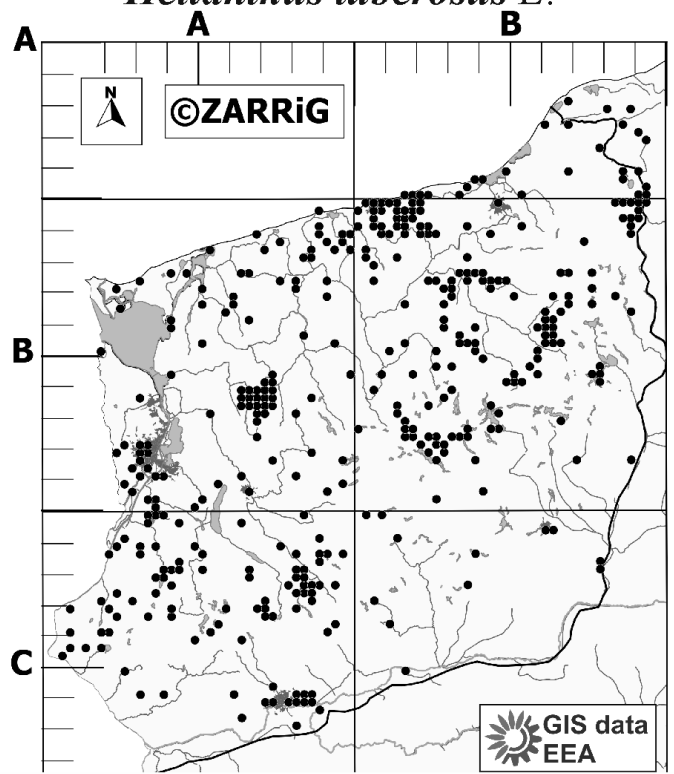

Heracleum sosnowskyi Manden.

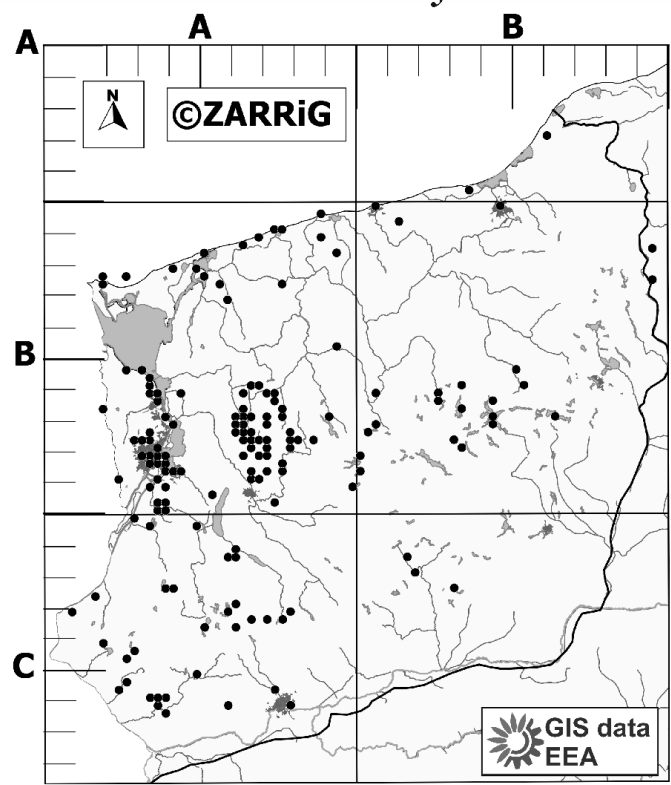

Impatiens glandulifera Royle (I. roylei Walp.)

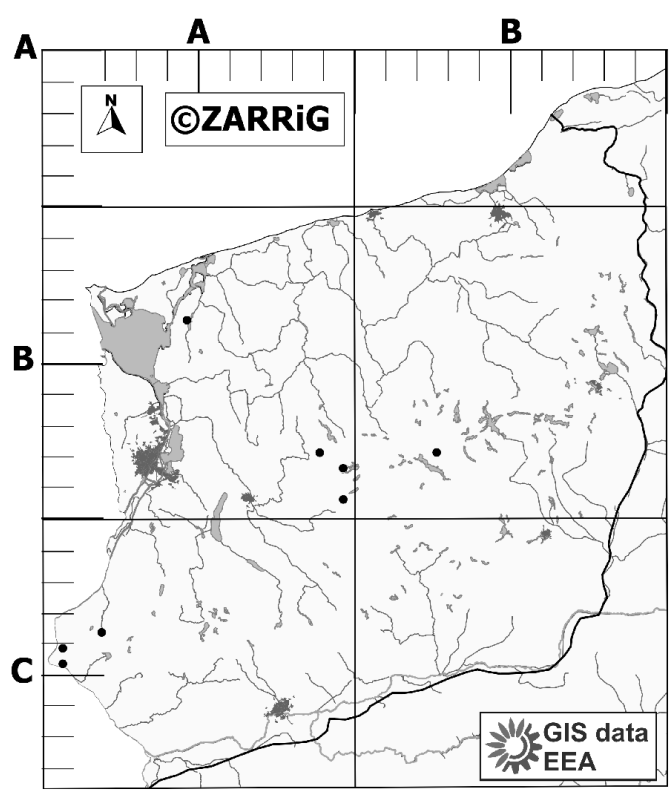

Heracleum mantegazzianum Sommier \& Levier

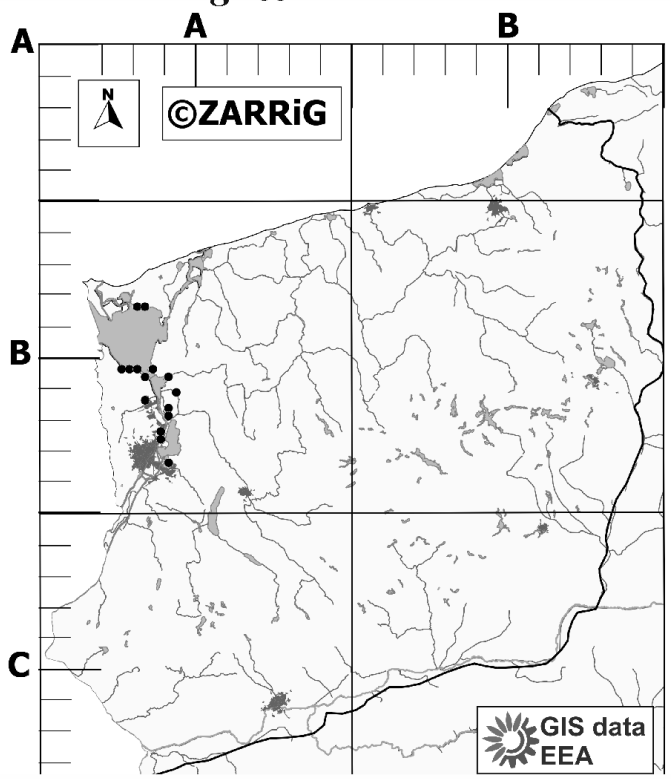

Impatiens capensis Meerb.

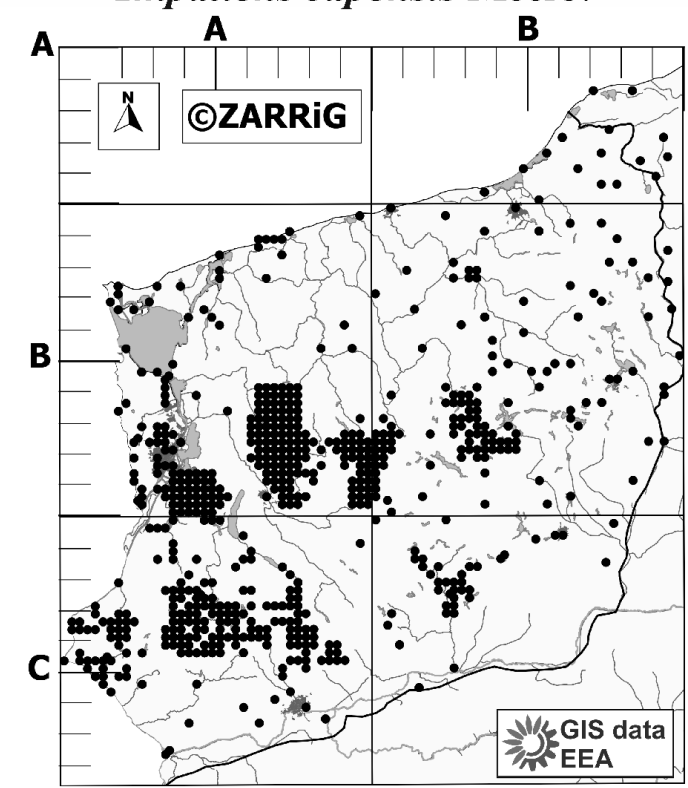

Impatiens parviflora DC. 


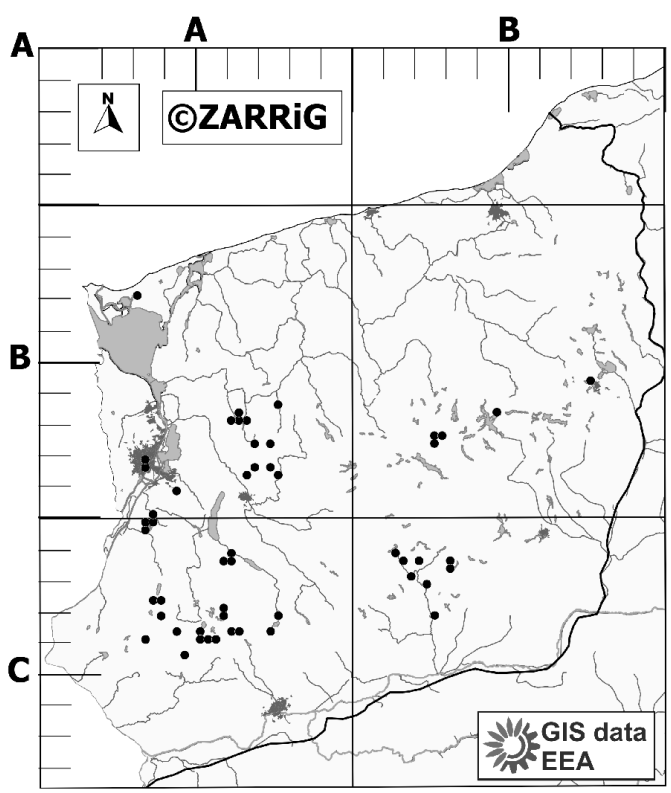

Juglans regia L.

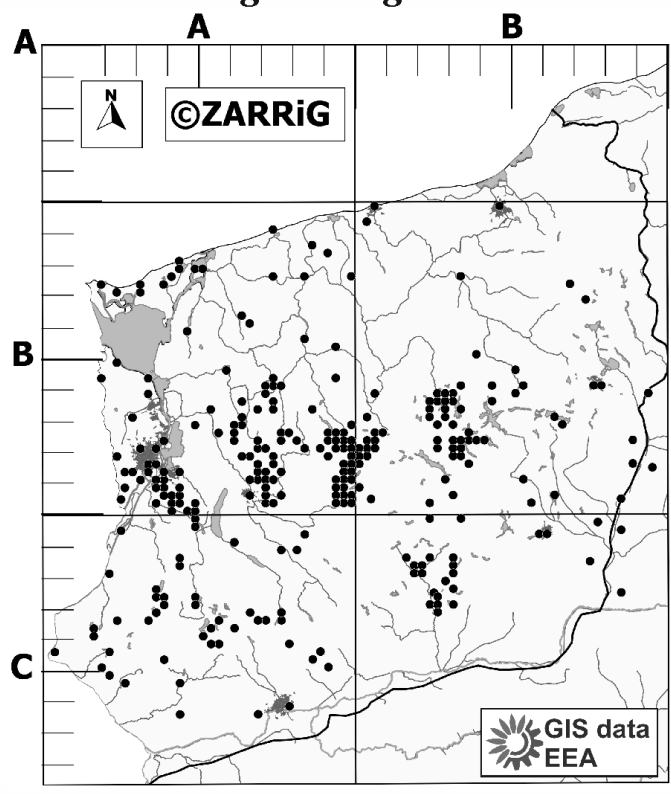

Lupinus polyphyllus Lindl.

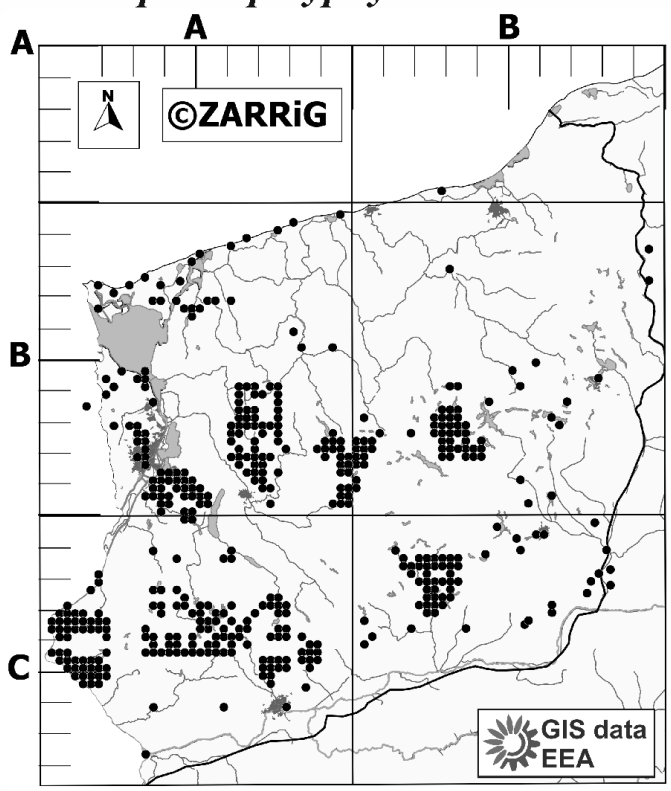

Padus serotina (Ehrh.) Borkh.

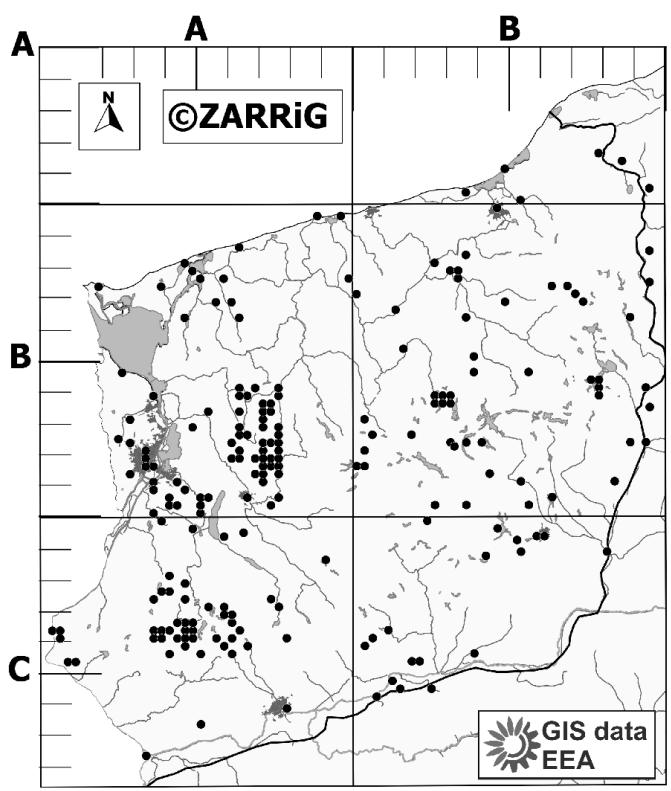

Lolium multiflorum Lam.

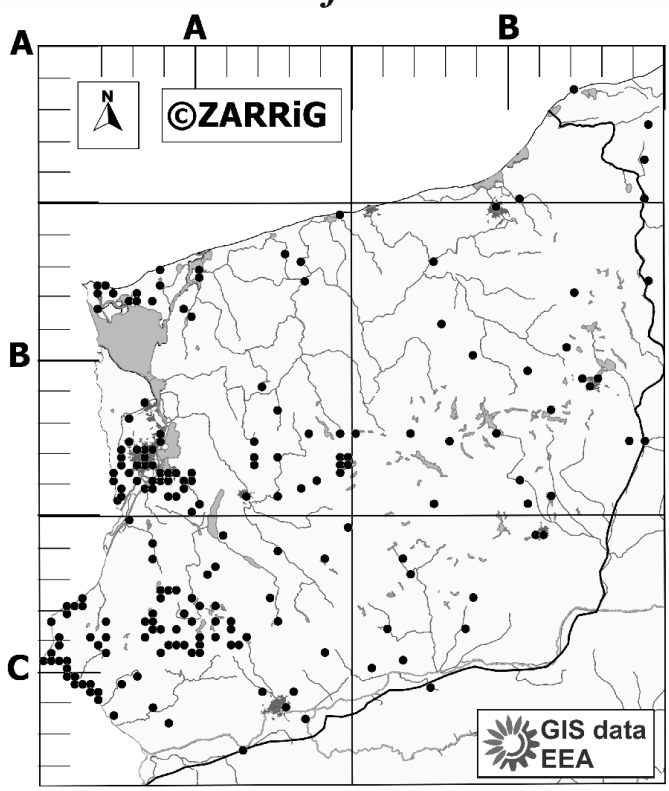

Lycium barbarum $\mathrm{L}$.

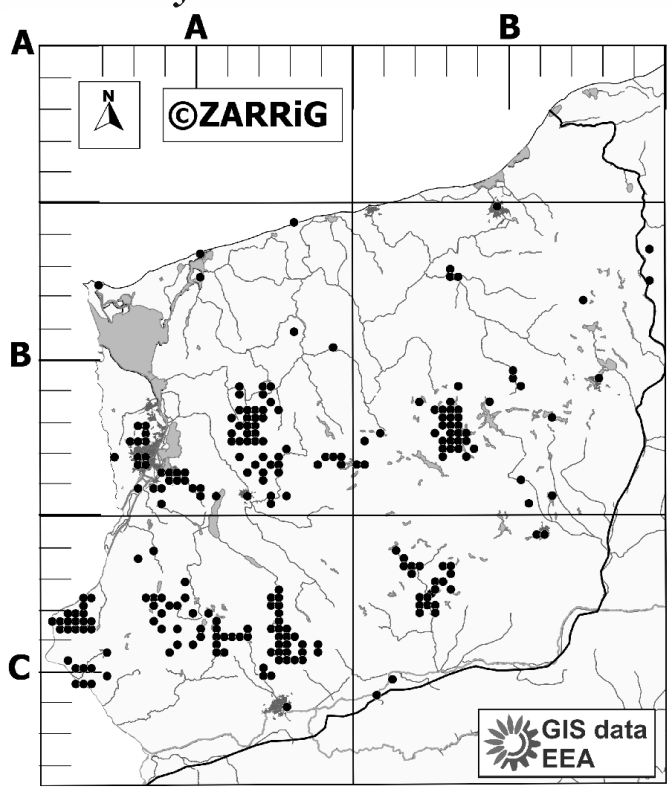

Quercus rubra L. 


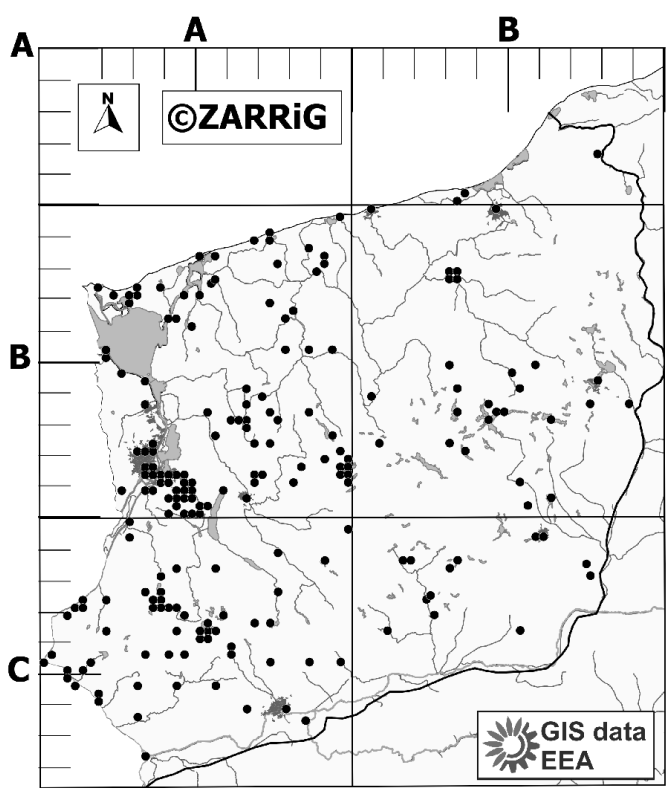

Reynoutria japonica Houtt.

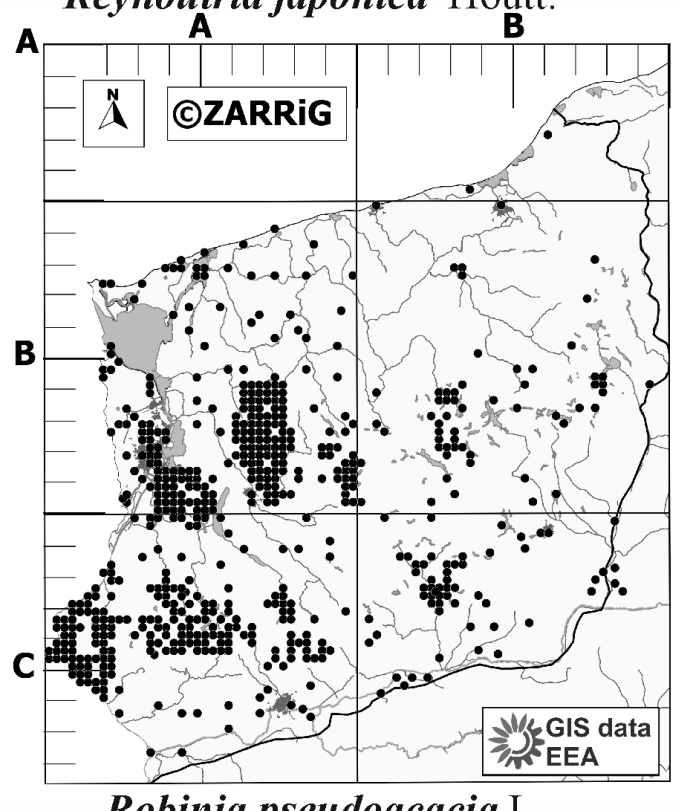

Robinia pseudoacacia $\mathrm{L}$

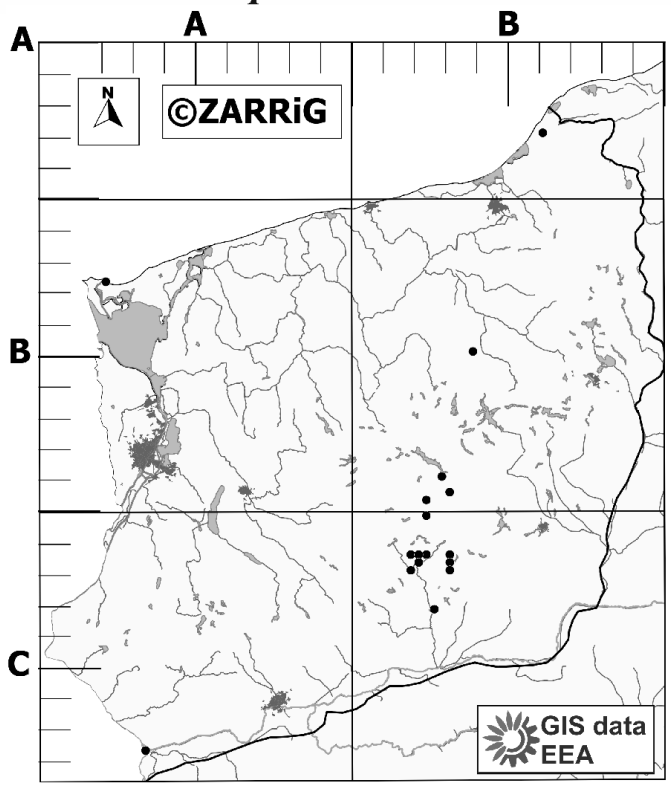

Salix acutifolia Willd.

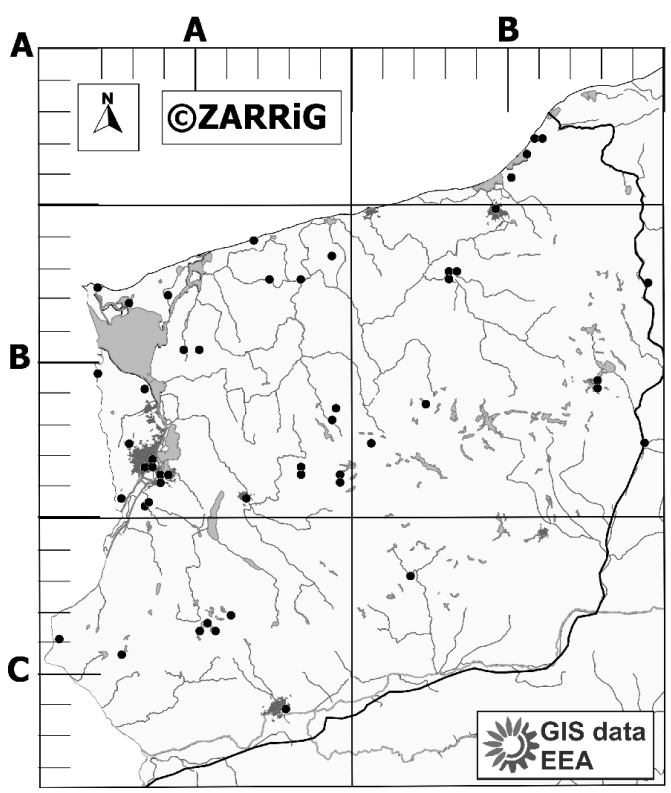

Reynoutria sachalinensis (F. Schmidt) Nakai

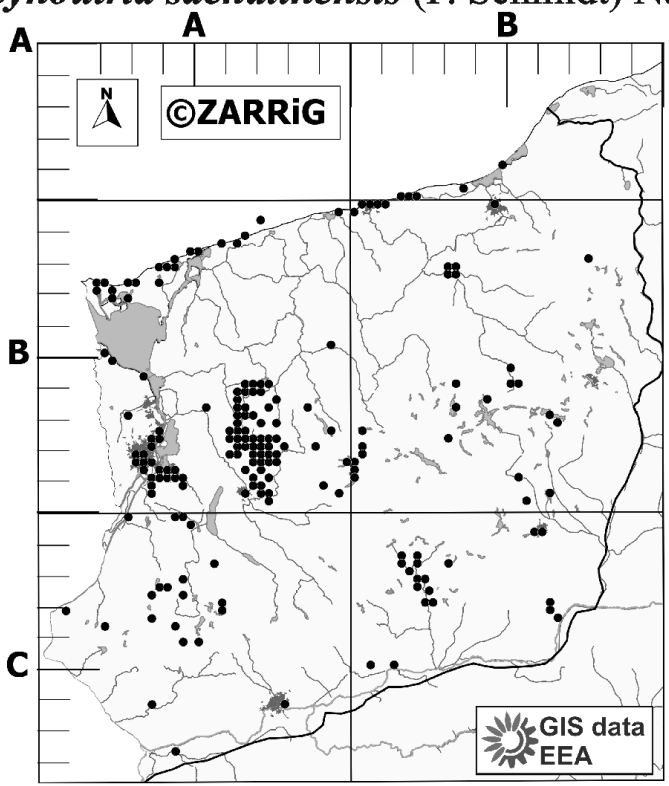

Rosa rugosa Thunb.

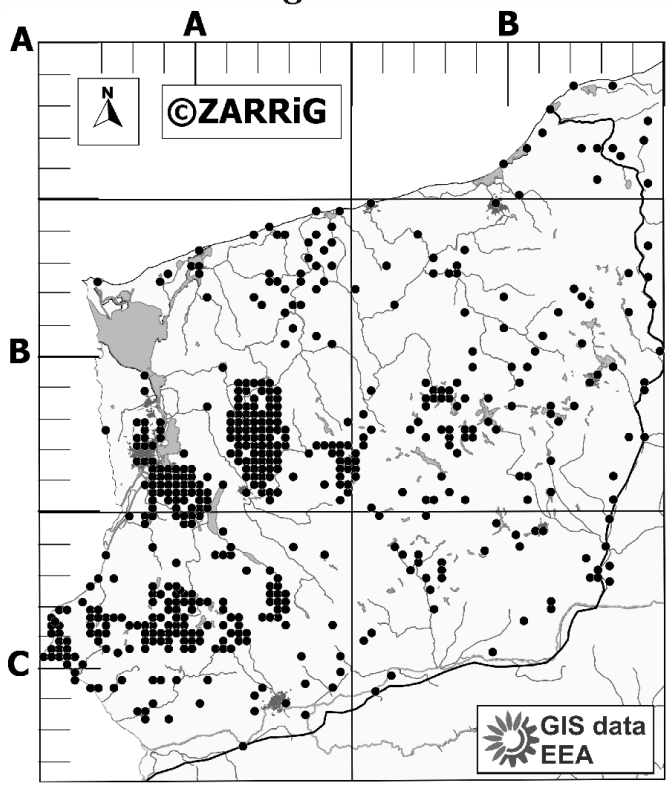

Solidago canadensis L. 


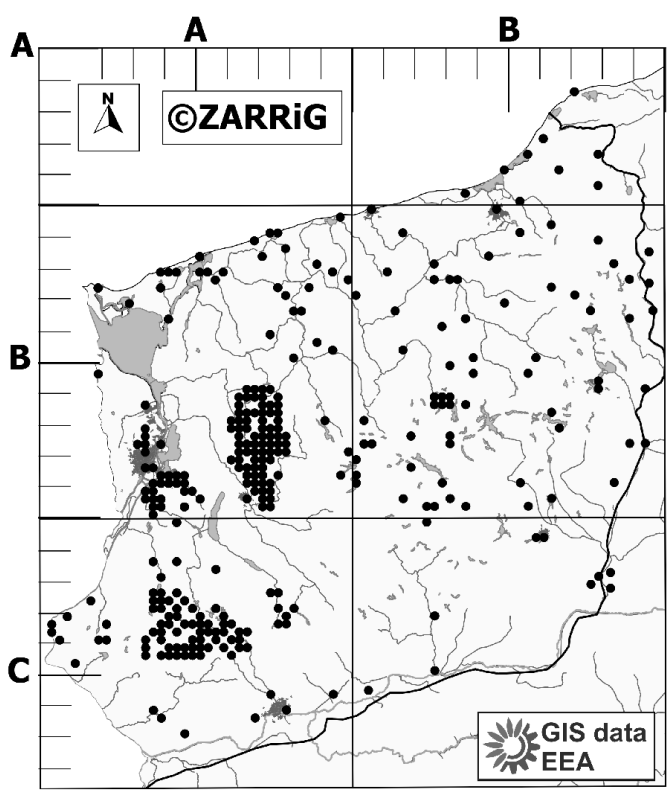

Solidago gigantea Aiton

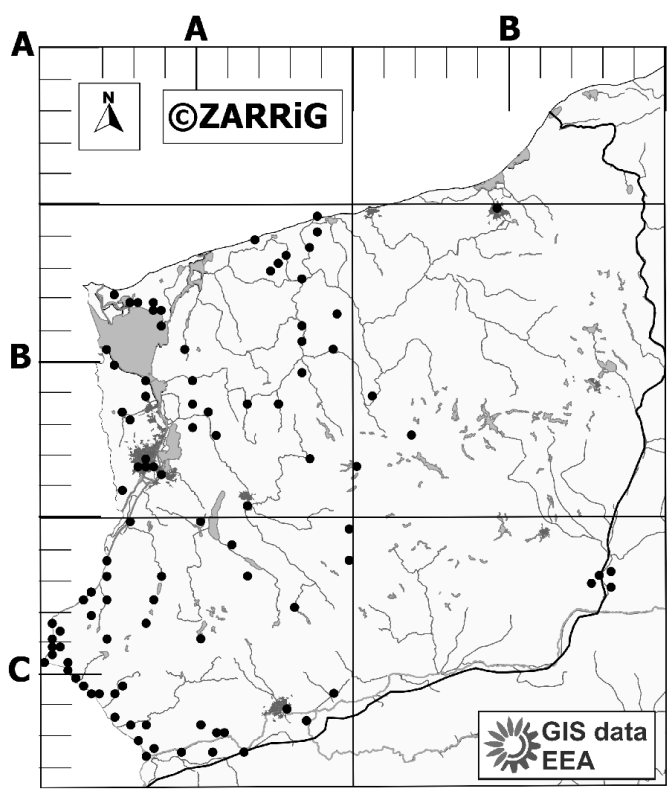

Xanthium albinum (Widder) H. Scholz 